\title{
TRANSMITTING THE PAST IN SOUTH SULAWESI: THE HIKAJAT SAWITTO AND OTHER BUGIS AND MAKASAR HISTORICAL WORKS
}

\author{
Stephen C. Druce $e^{* 1}$ \\ The Academy of Brunei Studies, Universiti Brunei Darussalam, \\ Tungku Link, Gadong BE 1410, Brunei \\ email: stephen.druce@ubd.edu.bn
}

Published online: 15 September 2016

To cite this article: Druce, S. C. 2016. Transmitting the past in South Sulawesi: The hikajat Sawitto and other Bugis and Makasar historical works. In Orality, writing and history: The literature of the Bugis and Makasar of South Sulawesi, ed. Druce, S. C. International Journal of Asia Pacific Studies 12 (Supp. 1): 73-117, http://dx.doi.org/10.21315/ijaps2016.12.s1.5

To link to this article: http://dx.doi.org/10.21315/ijaps2016.12.s1.5

\begin{abstract}
The central focus of this article is the hikajat Sawitto (hS), a 12-page typed text in the Latin script and Malay language constructed in the 1930s from mainly oral Bugis sources. The hS provides an important insight into how the past was transmitted in South Sulawesi and the relationship between orality and writing. Discussion of the $h S$ is framed within this broader context and begins with an overview of Bugis and Makasar ${ }^{2}$ historical prose works, focusing mainly on the few longer written compositions dating from the 17th, to the 18th, 19th and 20th centuries, and the factors that influenced their creation. Central to the article is the argument that these written works are not representative of Bugis and Makasar historical sources and that orality played the primary role in transmitting the past. The article further demonstrates how the hS was constructed from independent sources and what these sources can reveal about the history of Sawitto. An annotated translation of the hS is presented within the article and the original appended.
\end{abstract}

Keywords: Orality, writing, oral tradition, chronicles, Bugis and Makasar 
This article is concerned with South Sulawesi historical prose works in general, and more specifically, a modern historical work created in the first half of the 20th century called the hikajat Sawitto: What I heard from the Matoa of Depang and Uwaq Dadi (hereafter $h \mathrm{~S}$ ). ${ }^{3}$ The $h S$ was discovered loosely inserted in a 19th-century manuscript written in the Bugis script that was microfilmed in the 1990s by the Makassar Branch of the Indonesian National Archives. ${ }^{4}$ Unusually for South Sulawesi texts purporting to tell of the past, the $h \mathrm{~S}$ is a 12-page, typed text in the Latin script and Malay language that mostly follows the orthography set out by Van Ophuijsen at the beginning of the 20th century. ${ }^{5}$ It further differs from other Bugis texts about the past in that the creator comments in places on sources used, in an attempt to elucidate some of their more obscure contents, particularly in his attempt to create a list of Sawitto's rulers. Four neighbouring kingdoms that from the 16th century formed with Sawitto a confederation called Ajattappareng, "[The lands] west of the lakes," also feature prominently in the text, as does the mountainous Toraja region to the north. ${ }^{6}$

The article first presents an overview of South Sulawesi historical works written in prose, focusing mainly on a small number of longer written works dating from the 17th, to the 18th, 19th and 20th centuries, and the factors that influenced their creation. The following section introduces the $h \mathrm{~S}$ and discusses its background, the probable reasons for its creation, and its relation to other written Bugis and Makasar works previously mentioned. An annotated translation of the $h \mathrm{~S}$ is presented, followed by a discussion and analysis of its sources that aims to determine what the $h \mathrm{~S}$ can tell us about Sawitto's past, how this past was perceived and transmitted, and the relationship the text portrays between orality and writing. A reproduction of the original text with notes follows the study's conclusion.

\section{SOUTH SULAWESI HISTORICAL WORKS}

Some years ago, Campbell Macknight (1984) addressed the problems of defining and identifying a "work" in the South Sulawesi manuscript tradition, and the issues confronting perspective editors of texts produced by a society that had no concept of publication. Macknight defined a work as an original composition represented by a body of text that held a unity in the mind of its creator. Such works were not necessarily composed of entirely original material but may consist of formerly independent oral and written material brought together in order to create a new work. Drawing partly on an article by Christian Pelras (translated in this issue), Macknight emphasised that a new work may initially have been a written or oral 
creation and its transmission could be through either, or both, of these registers. In their written form, most works are found in codices of varying length that contain a wide-range of miscellaneous works in the form of independent texts. ${ }^{7}$ The codex essentially functions as a depositary for these independent works that are the units upon which attention should be focused, rather than the codex as a whole.

Macknight (1984) was concerned with "works" in general, but his observations are particularly pertinent to texts of a historical nature written in prose. Such works include both oral traditions about the past that were recorded in writing and written creations constructed by the author from diverse sources. Regardless of whether these historical works originated in the oral or written register, they are referred to respectively by the Bugis and Makasar as attoriolong or patturioloang, "[writings] about the people of former times." These terms have sometimes been translated to mean "chronicle", which is misleading, as the vast majority of these writings or works are nothing like chronicles.

Most attoriolong and patturioloang are derived from oral traditions that were set down in writing in bound codices of European paper, or used by the copyists of those codices to form new, composite works. No Bugis or Makasar codex is older than the late 18th century, yet the traditions, or works, they contain are frequently much older. Generally these works are between one to three manuscript pages in length $;{ }^{9}$ most are concerned with the origins of kingdoms and the ruling elite and set out the appropriate status for this elite. Others are concerned with relationships between kingdoms and recall significant events, such as wars and treaties, or set out boundaries between settlements. Direct speech is common in these works and there is rarely a sense of a narrator. Chronological information is largely absent, with events linked by phrases such as "some time later," or "it later happened." Many of these traditions continued to be transmitted in the oral register after being written down and underwent various transformations as their functions and purpose changed to reflect the needs and interests of later generations. Some oral traditions were collected by Dutch colonial officials, and some by modern researchers, and it is possible to make comparisons between these and versions recorded earlier in writing.

Longer written compositions about the past created from diverse sources are much fewer in number, but have attracted the greatest attention from both local and foreign scholars. The best known are the chronicles written in the 17th century for the kingdoms of Gowa, Talloq, Boné and Wajoq. ${ }^{10}$ The first to be composed were probably those of the Makasar kingdoms of Gowa and Talloq; these were influenced, and perhaps inspired, by Portuguese and other European models (Macknight 2000; Druce 2009: 
71-72). Those of Boné and Wajoq were composed in the late 17th century: as Macknight (2000: 235-236) has observed, the Boné chronicle appears to be a riposte to that of Gowa. The Talloq and the earliest of the Wajoq chronicles close with events in the mid-17th century (Noorduyn 1955: 143), and those of Boné and Gowa in the late 17th century. Only in Wajoq was the practice of chronicle writing resumed, but this was a century or so later and appears to represent a new tradition of chronicle writing that is addressed below.

These 17th-century chronicles are markedly different in nature to the more typical orally-derived historical works, in that they demonstrate a degree of editorial skills, such as the selection, rejection and amalgamation of various oral and written source materials in order to create a new and longer written work. Other contrasts are that the chronicles have a clear sense of narrator, and the narrative styles used to relate events occurring under different rulers are simple, straightforward and concise. Chronological data is also used, such as the number of years a monarch ruled and the time between events that take place, although this is more evident in sections concerning the 17th century. Dates rarely appear in early sections, but both Christian and Islamic years are sometimes given in parts that deal with 17 th-century events.

Genealogies were the most important source materials for the chronicles. Genealogies are probably the most abundant genre of Bugis and Makasar writings (Caldwell and Wellen 2016) and it was perhaps their existence that made it possible to write the chronicles. ${ }^{11}$ Other important sources were oral traditions, some of which may have been inscribed on palm-leaf, while others presumably were collected by the chroniclers. A number of these traditions, and most of the genealogical information used, can still be found in unedited form within Bugis and Makasar codices. The chronicles were essentially political and ideological works and, like the genealogies they are structured around, their purpose "was to set down a statement of the status of the rulers and the ruling group more generally," and a purpose that is clearly expressed in their opening sections (Macknight 2000: 326).

The resumption of chronicle writing in Wajoq in the 18th century led to a work of extraordinary length known as the Lontaraq Sukkuqna Wajoq (Complete Chronicle of Wajoq, hereafter LSW). There are two known copies of this manuscript, the longest of which is in excess of 600 manuscript pages. ${ }^{12}$ The LSW covers the origins of Wajoq until the late 19th century and, unusually for Bugis historical sources, relates events that took place in other parts of South Sulawesi. It is more detailed than other Wajoq sources and includes dates, adat laws, songs, and some details of contracts 
made with the Dutch East Indian Company (VOC). Andi Zainal Abidin, who translated and published the 15th and 16th century sections of this work (Zainal Abidin 1985: 32-33), was told in 1967 by Andi Makaraka that the LSW was first composed between 1764 and 1767 after numerous other written sources from Wajoq and many other places in South Sulawesi had been collected and compared. ${ }^{13}$ The LSW was revised and updated by later writers. The most recent revision was in the 1940s by Andi Makkaraka, who added the 19th-century sections (Zainal Abidin 1985: 529). This practice of periodic updating and revising appears unique to the Wajoq chronicle tradition. Kathy Wellen (2014: 172) believes the date of the LSW's initial composition was later than Abidin was told and suggests the inclusive nature of the work was "a desire to elevate Wajorese historiography to a new level" that perhaps grew from "a familiarity with Dutch historiography" rather than Portuguese historical works. ${ }^{14}$

Given that the LSW was regularly updated, and on occasions rewritten, it is not surprising that it reflects 19th and even 20th century interests, which are projected back to earlier periods in Wajoq's history. In particular, much emphasis is placed on the freedom of Wajoq people that resonates in the words reputed to have been spoken by 15th century and later Wajoq rulers. Noting that the work was written after Wajoq's liberation from Boné in 1737, Reid (1998: 148) suggests that such declarations of freedom were placed in the mouths of these early rulers by later writers. Likewise, the origin of Wajoq set out in the LSW is more rational than the mythical accounts found in the earlier chronicle tradition and in various oral traditions. ${ }^{15}$

Several hundred years after the first chronicles were composed, in very different historical times, there were further attempts to create comparatively long written histories for a number of Bugis and Makasar kingdoms. Unlike the earliest chronicles, in most cases we know the authors of these later works. I am aware of four such works written in the 19th and 20th centuries for the kingdoms of Tanété, Maros, Sawitto and Sidénréng. Those of Tanété and Maros were linked to Dutch interest in Bugis and Makasar writings, in particular that of B. F. Matthes, the Dutch linguist and missionary, who lived in Makassar in the mid-19th century.

The earliest and longest of these is the Tanété chronicle, written in the mid-19th century by Colliq Pujié, a daughter of the ruler of Tanété. ${ }^{16}$ Colliq Pujié was well versed in Bugis literature and an important informant of Matthes. Indeed, it was at Matthes' request that she wrote the chronicle, or history, of Tanéte (van den Brink 1943: 172-173). ${ }^{17}$ As with the 17th century chronicles, the chronicle of Tanété relates to events that took place under successive rulers, but its purpose and style are quite different. Unlike 
most Bugis and Makasar works that tell of former ruling ancestors, the Tanété chronicle begins not with self-reproach by the writer for daring to mention ancestral names, but simply gets on with the telling the story of Tanété. ${ }^{18}$ The writing style is livelier and more engaging than the 17 th century chronicles and the work is less centred on genealogies. There is also greater use of direct speech in the story and an absence of even basic chronological data with successive rulers and events connected by phrases such as "some time later" or "some years later." Reading the Tanété chronicle the impression one gets is that much of Colliq Pujié's work is based mainly on a collection of oral traditions, some perhaps recorded earlier in writing, linked together by a skilled writer. Prior to Matthes' request that a chronicle of Tanété be written, it is conceivable that Colliq Pujié had never considered such an undertaking.

The Maros chronicle, written in 1889 by I Sahban Daeng Masikki, is a very different work to the Chronicle of Tanété in style, structure and purpose. The Maros chronicle closely resembles the Gowa and Talloq chronicles written more than 200 years earlier. The reason for these similarities appears to be because Daeng Masikki was one of the Makasar assistants who acquired, translated and copied texts for Matthes or perhaps other Europeans in the 19th century (Cummings 2000: 2). In this role he came into contact with various Makasar texts, in particular the Gowa and Talloq chronicles. These appear to have been partly responsible for inspiring Daeng Masikki to write a similar work for Maros. The Gowa and Talloq chronicles also functioned as stylistic and structural models and were important sources of information for Daeng Masikki, who directly copied and integrated several of their sections into the Maros chronicle (Cummings 2000: 23).

As Cummings (2000: 25-27) argues, another reason for writing the Maros chronicle was related to the shifting political order of the late 19th century, during which Maros became more aligned with the Dutch. As political boundaries were demarcated and clear succession procedures set out, a written history would have provided Maros and its claims greater legitimacy in the eyes of the Dutch, who considered written histories more reliable and legitimate than oral accounts. ${ }^{19}$ In this context, it should be noted that Daeng Masikki not only imitated the style and structure of the Gowa and Talloq chronicles but also acquired the same paper used for Matthes' Makassaarsche Chrestomathie, and attempted to replicate in his writing the font that was used to print these texts, in order to make the Maros chronicle look legitimate and official (Cummings 2000: 28). As with the 17th century chronicles and Colliq Pujié's work, the creation of the 
Maros chronicle appears to have been profoundly influenced by a European presence in the region.

Perhaps the last work written in the Bugis script that can be described as a chronicle is the akkarungeng Sawitto composed by Haji Paewa in the second half of the 20th century after the South Sulawesi kingdoms no longer existed. A photocopy of the akkarungeng Sawitto in my possession is signed by the author and dated 20 April 1981, but it is unclear whether this date relates to the completion of the original manuscript or to a copy made by him. ${ }^{20}$ There is no relationship between this chronicle and the $h \mathrm{~S}$, despite both being concerned with Sawitto, and none of the $h S^{\prime}$ s traditions relating the origins of Sawitto appear in Haji Paewa's work. As with the earlier chronicles the akkarungeng Sawitto is largely structured around the reigns of rulers, but covers an even longer period of history than the LSW, beginning with the origins of Sawitto and ending with events in the 1960s. Despite this, it is only 23 manuscript pages in length. Much of the chronicle is concerned with the 19th and 20th centuries; earlier sections are based on data derived mostly from oral traditions, probably collected by Haji Paewa himself.

Haji Paewa's chronicle is interesting for several reasons. Unlike earlier chronicle writers he did not just use local oral and written material but also information from printed books and articles. Also of interest is that versions of some oral traditions he collected had been recorded in written form at least 200 years earlier and are found in 18th and 19th century manuscripts to which Haji Paewa may not have had access. While the oral traditions he collected still contained a broadly similar outline to the written versions, their functions had changed markedly to reflect the interests and needs of post-independence Indonesia. ${ }^{21}$ People who knew Haji Paewa informed me that he decided to write this chronicle, and other works on Sawitto, as none appeared to exist for this kingdom. ${ }^{22}$

The last work to be discussed here from Sidénréng is by far the least sophisticated. ${ }^{23}$ This work is not a chronicle but an account (attoriolong) of the origin of the kingdom, its founding rulers, and the laws and administration they are credited with establishing. This work was probably produced in the 19th or 20th century and the creator is unknown. The Sidénréng attoriolong comprises 14 short independent oral traditions that have been placed one after the other with little attempt at integration. Each tradition is linked only by the opening gloss added in order to associate it with the kingdom's founders. ${ }^{24}$ Despite the rudimentary integration of its source material, the Sidénréng work does have a conceptual unity, in that it begins and ends with an oral origin tradition that tells of the kingdom's founding. This origin tradition serves as the work's creative framework and 
all other traditions presented have been purposely enveloped within the foundation tradition. Many of these secondary traditions presented are concerned with customary laws and rights, and while some (such as the ruler's monopoly on tobacco and opium) clearly derive from a later period in the kingdom's history, their association with Sidénréng's founders gives them the highest legal authority.

From the foregoing discussion, it is apparent that one cannot speak of a single South Sulawesi chronicle tradition but of "chronicle traditions" that emerged at different times for various reasons. A European influence can be detected in the production of most of the chronicles but the works themselves reflect indigenous concerns from different historical periods and were shaped to support a contemporary position, reality or purpose. In the case of the LSW, later writers may have even reshaped this chronicle to reflect changes in the Wajoq worldview. European influence also appears to lie behind the creation of the $h \mathrm{~S}$ but this "work" is of an entirely different nature to the chronicles discussed above.

\section{THE HIKAJAT SAWITTO}

In a section of the $h \mathrm{~S}$ concerned with genealogical information, the writer mentions that Andi Baeda is the current ruler of Sawitto. This allows us to date the hS's creation from between 1922 until 1940, the period that she ruled Sawitto as a swapraja under the Dutch colonial administration. ${ }^{25}$ The $h \mathrm{~S}$ was thus created in the context of Dutch colonial rule, sometime in the 1920 s or 1930s. Such an early date for a typed text about Sawitto in the Latin script and Malay language is surprising. Few people in Sawitto would have spoken or read Malay at this time and the use of this language and script instead of Bugis suggests that the $h \mathrm{~S}$ was not produced for local consumption. Malay was, however, the primary medium of lower levels of the colonial Dutch administration and the use of Latin script and a typewriter suggests that the author of the $h \mathrm{~S}$ was connected to, or even employed by, the colonial government. A Malay text in Roman script would have been of little utility for the people of Sawitto, but useful for a Dutch official who wanted to know about the region and its past. The most probable reason for its creation is that the $h \mathrm{~S}$ was commissioned by a Dutch official and created by a local assistant employed by the colonial administration. The text may have been typed in Makassar but it is clear that the information was collected from local informants in Sawitto. The most likely Dutch official to commission such a work during this period would have been A. A. Cense, who had a deep interest in South Sulawesi history 
and literature and later published a number of articles on the subject. Most of Cense's papers and notes were lost during the Japanese occupation and it is just possible that the $h \mathrm{~S}$ is a scattered part of these papers. ${ }^{26}$

When reading the $h \mathrm{~S}$, the initial impression is that it appears to be yet another attempt to create a cumulative, narrative account of the past, albeit in the Malay language, from more typical and shorter independent sources. Indeed, the first six and half pages present five different oral traditions of varying length that were presumably told by the matoa of Depang and Uwaq Dadi, whose names appear in the title. In these first six and a half pages there appears little input from its writer, apart from bracketed Indonesian translations of some Bugis words and sentences that appear in the text. In the remaining five and a half pages this impression changes and it becomes clear that the $h \mathrm{~S}$ 's structure and purpose is different to the earlier and later chronicles in that it does not share the same sense of contextual unity. After these five oral traditions, the $h \mathrm{~S}$ focuses on genealogical information, and written sources are used. The authorial voice becomes prominent as the writer attempts to create a list of rulers for Sawitto from oral traditions, which he refines in consultation with a written text. Various shorter traditions and information relating to Sawitto are presented towards the end of the $h \mathrm{~S}$.

While the $h \mathrm{~S}$ is an attempt to create a new longer written "work" about Sawitto's past, unlike the chronicles we have discussed, it exhibits a more modern historiographical consciousness in that some data collected is assessed and judged. This sets the $h \mathrm{~S}$ apart from both written works (such as the chronicles) and oral traditions preserved in writing, both of which present information as an uncritical integrated whole in order to fulfil a particular function and purpose. Rather, the purpose of the $h \mathrm{~S}$ appears to be an attempt to write an account of Sawitto's history acceptable to an early to mid-20th century audience, despite evident analytical shortcomings and a literal acceptance of the oral traditions.

Despite being typed in the Malay language, the $h \mathrm{~S}$ is not an easy read. Few "Indonesians" were fluent in Malay in the 1930s and the author's use of the language is at times rudimentary and difficult to understand, perhaps partly because informants would have related their information in Bugis, and some of this proved difficult to translate. There are numerous spelling and grammatical errors, and in places inconsistent use of speech marks. In the translation presented below, I have retained the Bugis words and sentences that appear in the text and present them in italics. I have, however, changed the orthography and made some corrections. Where the original text provides no translation for Bugis words a gloss is given in endnotes. My own additions are presented in square brackets. In order to aid 
understanding of the $h \mathrm{~S}$ 's structure, I have separated the various traditions and information into sections with headings. Where expedient the headings are followed by explanatory comments on the section that follows. Further comments are given in endnotes. ${ }^{27}$

\section{The hikajat Sawitto: What I heard from the matoa of Depang and Owaq Dadi}

\section{Tradition 1}

Long, long ago there were three siblings who were descended from the ruler of Luwuq. Each of them had hundreds of followers. These lords were descended from the pajung of Luwuq. ${ }^{28}$ At this time there were people living in Sidénréng, Rappang and Sawitto but they did not yet have any rulers. So the three lords travelled to those places. [They] stopped in Sidénréng and the three asked "what is it that is long"? The people there answered: "Those are the kuli-kuli of Sidénréng." 29 "If that is so, then I will name this place Sidénréng. It would be good if the middle sibling becomes ruler here. ${ }^{30}$ So that place was named Sidénréng (kuli-kuli - kaleleng) ${ }^{31}$

After that the other two continued their journey. They came upon a river in Rappang. This river was piled with debris. [They] asked the people [there]: "What is it that is filling up the river?" The people there answered: "That, it's called rappang." The royal descendants answered: "If that is so then it would be good if your land is called Rappang." ${ }^{32}$ So the youngest became the ruler there. The eldest went westwards and came upon a land where he found a large tree. He asked the people [there]: "What tree is this?" The people in that place answered: "It is called a sawitto." So he stayed in the land and called the land Sawitto. ${ }^{33}$ So it happened, the three siblings became rulers of Sawitto, Sidénréng and Rappang.

\section{Tradition 2}

Comment: Several versions of this second tradition have been recorded in the Bugis script and oral versions are known by a few people in the Sawitto region (Druce 2009: 188-192). None begin with the confused paragraph below but with the paragraph that follows about the male child who arose in the Saddang River's headwaters. The apparent restructuring of the tradition's opening appears to have been done in order to connect it with the first tradition. Whether this was the work of the $h$ S's writer or the matoa of Depang and Owaq Dadi is impossible to tell. 
At that time the people of Palétéang, the people of Anaq Banua, effectively [all] the people to the west of the Saddang [river] (the course of the Saddang was different at that time ${ }^{34}$ ), that is that none of the lands to the west of the river, wanted to be ruled by him.

During this period a male child arose in the headwaters of the river Saddang. It was said the ruler of Sangallaq had dreamt that on a certain day a large piece of bamboo would be seen flowing upriver. The ruler of Sangallaq went down to the river and saw the bamboo, then there was noise all around and a royal [boy appeared from the bamboo]. ${ }^{35} \mathrm{He}$ took him to the palace. When the boy arrived at the palace two sets of nine wet-nurses were found for him.

A few days later the wife of the ruler of Sangallaq had a dream in which a person spoke to her and said: "Tomorrow you will find foam flowing upstream. Take the foam and bring it to the palace." The next day the wife of the ruler went to the river and she found the foam and took it with great reverence to the palace. The foam split open and out came a girl. Two sets of nine wet-nurses were found for her.

When both [children] were grown up, the boy was allowed to take a wife and the girl was allowed to take a husband. So they were married to each other (in the way of former times). From this marriage there were eight children. The eldest and the youngest were girls. The eldest took a husband in the upper reaches of the Saddang. She was the ancestor of the ruler of Énrékang and the ruler of Batulappa.

Said the [two] tomanurung: ${ }^{36}$ "Our oldest child has a place [but] where will our other seven children go? Where shall we place them?" The man said: "There is a land to the south of this land that is called Sawitto. It would be good if we tell the seven to go there. There is a village called Lamadimeng, it would be good if we tell them to go there. They can work gardens there." So the seven went to Lamadimeng. There they cultivated sugar cane, taro, bananas and other crops.

One day [one of the siblings] went to the market to sell their sugar cane and chatted with a servant of the ruler [of Sawitto], who said: "Every day we go to war, after Malimpong, then Talabangi opposes [us]." The sibling ${ }^{37}$ said: "If the ruler [of Sawitto] will reward us with things that we desire [then] we are prepared to fight against the ruler's enemies." Then suddenly one day she was seen by the ruler. The ruler said: "Who is this person that sells sugar cane and appears so different?" Another person said: ${ }^{38}$ "That person comes from the mountains, she lives in Lamadimeng [with her brothers] and they work gardens, my lord. She is too proud to say that they would oppose my lord's enemies." The ruler ordered the female sibling to be called to the palace. After the female sibling arrived at the 
palace the ruler told [her of the problem]: "Now there are these people of Palétéang who I cannot subdue, they refuse to follow my rule." She replied: "We are capable of subduing the people of Palétéang so they submit to [their] ruler." "That is good," said the ruler. "If you can defeat the people of Palétéang, I will give you titles in Sawitto and eloqmu kuwa adamu tongeng ritanaé ri Sawitto (which means, "your wishes shall be granted and your words are true in the land of Sawitto").

Afterwards she went back down to the market. Then she gave away her sugarcane and went back home. When she arrived at the house she told her brothers [what had happened]. She said: "We are unfortunate, we have been ordered by the ruler to go and fight against the people who are unwilling to follow his rule." Her brothers said: "This is good, do we not have a mother and father whose origins are from the sky?" In short, three of the siblings were ready to go to war against Palétéang, and Palétéang was defeated by them, as were Lampangeng, Bulu and Saloq. Then they returned home. Three others also went to war against Pesoq, Bulu, Sékkang and Bua, then they went back to their home. The other [three] also went to war against Madelloq, Paria, Cempa and Tampia, then returned home. The three others then defeated Padakalawa, Kaqba and Punia. And so it happened that they defeated all [the lands opposing the ruler]. ${ }^{39}$

Afterwards they waited for the ruler to give [what was promised but] it never came. When the ruler was sitting by the window looking out and the children of the manurung passed, he closed the window. After waiting a long time for the promised rewards from the ruler that were not given, they went and called the people of Palétéang to take revenge against the wicked ruler. So there was a war between Sawitto and the people of Palétéang [who were] with the children of the manurung. The ruler ran away to Bélokka. Then the children of the manurung agreed with the other people that the female child of the manurung become the ruler and her brothers would have the title arung ennengngé. ${ }^{40}$ She ruled in Sawitto, Sidénréng [and] Rappang because at that time they did not have rulers. 


\section{Addition to the Tradition}

Comment: the following paragraph is not part of the tradition told by the matoa of Depang and Owaq Dadi but an addition from another informant, referred to as the head of Sempang. This addition represents a later innovation that serves as a gloss. It connects the first and second traditions by countering the final sentence above that states there were no rulers of Sidénréng and Rappang prior to the appearance of the divine couple. The use of speech marks for this additional paragraph indicates it is a direct quote from the head of Semapang and is separate from the tradition related above. It may have been related to the $h$ S's writer after he collected the above story and decided to present it as an alternative ending.

The head of Sempang said: "When the people of Palétéang and the children of the manurung waged war on the ruler [of Sawitto] he left for Rappang. But [they] chased after him. Together with his sibling [in Rappang] the ruler fled to Sidénréng. He was chased [to Sidénréng] too; eventually the three ran back to Luwuq."

\section{Tradition 3}

Comment: The first sentence in this third tradition is a gloss that attempts to link it to the above tradition.

After some time the female ruler married the ruler of Luwuq and they had a child who was titled La Mattanawali. He became the ruler of Sawitto, Rappang and Sidénréng and had the title akkaqdaoangngé. ${ }^{41}$ Now this La Mattanawali had a daughter and she married the arung Ujung in Soppéng. It was she who succeeded her father as akkaqdaoang in Sawitto, Rappang and Sidénréng.

At the time she was the akkaqdaoang of Sawitto the rice did not grow and the various fruits failed. So the people of Sawitto, Rappang and Sidénréng agreed to remove their ruler [from office]. They made a litter for her then carried her to the land of the Toraja, to the settlement called Randanan. She was placed [by them] in the middle of the common ${ }^{42}$ and left there. The people of Randanan picked up the ruler, and they made her their own ruler, because she had white blood. ${ }^{43}$

The people of Sawitto returned to Sawitto. Nothing was left of the crops, all was dry, even the animals were all dead. Only in Rappang could green leaves be seen. It was a time of great hardship for the people of Sawitto. 
Not long afterwards the people of Sawitto heard that the ruler they had taken to Toraja had given birth to two boys. The eldest was called La Pasalongi, the youngest La Mattambéro. The people of Sawitto and Sidénréng went to the land of the Toraja to find the akkaqdaoang. They found her in Randanan. Then they requested that her children become the rulers of Sawitto and Sidénréng. The instant they asked for her children she refused. She left Randanan and went to Makale. The people of Sawitto and people of Sidénréng returned home. After some time the people of Sawitto and the people of Sidénréng again returned to the land of Toraja to request [that] the two children become [their] rulers. Their mother answered: "Hey, you people of Sawitto and people of Sidénréng, surely among you there are those who have two children. Would you separate yourselves from those children? Go back to your lands." So the people of Sawitto and the people of Sidénréng returned to their lands.

Not long after this the people of Sawitto with the people of Sidénréng again agreed to go to Randanan. They took many women with them to Randanan. After they arrived in Randanan they took a vow. The akktaqdaoang said: "It is best you all just return. If it is predestined the gods will look [kindly] upon your land and there will be prosperity." After that the people of Sawitto and people of Sidénréng returned and waited for the arrival of the rulers.

After some time she sent her two children. The eldest was called La Pasalong, he was made ruler of Sawitto. The youngest was called La Mattambero and became ruler of Sidénréng. The common people asked what his name was [and] who it was who had been made ruler. ${ }^{44}$ Then people replied: Anaqna mua akkaqdaoangngé naqdéatuang polé ri Toraja, which means, "The child of the akkaqdaoang sent from Toraja." So for that reason their houses were called saoraja and he himself from that time was known as aqdatuang,"the one who was sent."45

That was the time when the rulers of Sawitto and Sidénréng first had the title aqdatuang.

\section{Tradition 4}

Comment: the following tradition is a well-known etymology of Alitta. The first paragraph does not appear in other known versions and functions to connect the tradition with the one it follows.

Then there was the request of the akkaqdaoangng to her children: "If you wish to find your family then go to Toraja, to Randanan, to Makale and to 
Batu, and if you have children, [one of you] a boy and the other a girl then you marry them to each other." Later, the one in Sidénréng had a boy and the one in Sawitto had a girl. So they married each other.

From this marriage there were four boys. The eldest became ruler in Sawitto and the second eldest became ruler in Sidénréng, the next became ruler of Rappang while the youngest became ruler in Suppaq.

Later they had another boy [but] there was no land for him to rule. Not long after there was a land at the foot of a mountain called Paqbola Batué. This later child was placed there to become its ruler. He was named petta Paqbola Batué. ${ }^{46}$ After some time the ruler of Suppaq came to see his elder brothers and asked: "What is our younger brother (anritta) doing?" ${ }^{47}$ The ruler [of Sawitto?] replied: "What can [he] do, yet he is still a young child. In that case then it would be good to call his land Alitta (anritta)."

\section{Tradition 5}

After that the rulers made a house in Sawitto with five divisions, each division was their own room. From time to time the five brothers would gather together in Sawitto and live there. It was there that the five brothers made the [following] agreements:

Temmaqbola sielleq (to be as one house and not be separate); siumang siliweng (to mutually work the rice fields in each other's lands); tessikaja lémpong-lémpong (none is permitted to catch fish in the others' fish ponds); wessé asé mappammasaq (our people remain loyal to their own ruler). ${ }^{48}$

\section{Genealogical Traditions with Additions from Written Sources}

Comment: the first sentence below is a gloss that links the following genealogical information to the above tradition. Written genealogies are consistent in naming the first two individuals named below as the children of the Sawitto ruler Paléatéang, whose name does not appear in the $h \mathrm{~S}$.

The one who become ruler of Sawitto had two children, a boy and a girl. The boy was called Cellaqmata and the girl was called I Jépo. ${ }^{49}$ Now this Jépo married with the child of the aqdatuang of Sidénréng who was called Basoq Massépé. ${ }^{50}$ Now Cellaqmata became the ruler of Sawitto. He also had a child who was called Torijallo (matinroé ri Maroli? ${ }^{51}$ ). 
In the lontaraq ${ }^{52}$ of paqbicra Andi Pawiloi it can be read that a certain datu of Suppaq betrothed his daughter, called Lampéwélua, [to a child of the ruler of Gowa ${ }^{53}$ ] but [the marriage] did not happen because the aqdatuang of Sawitto wanted Cellaqmata to marry Lampéwélua. Then Tunipalangga, the ruler of Gowa, became very angry and there was a war between Sawitto and Gowa. Seven times Gowa attacked Sawitto before finally defeating Sawitto. Then Lampéwélua was captured by the ruler of Gowa who took her to Gowa and tortured her. After, La Pancai was made ruler of Sawitto.

Who La Pancai was is not mentioned; perhaps he was also La Cellaqmata.

This Torijallo took the child of the aqdatuang Sidénréng as a wife who was called Tanruléq. Torijallo had a daughter called Tanrisuji. Tanrisuji married the Cakkaridi of Wajoq who was called To Patakka. ${ }^{54}$ Tanrisuji became aqdatuang of Sawitto and she was also the datu of Suppaq. She had four children, two boys and two girls. Now of the boys, the eldest was called La Makkasau who later became aqdatuang of Sawitto, and the girl called daéng Séo, she became the ruler of Patombong Makuring (which was later called Langa ${ }^{55}$ ). The other boy was called La Patombongi datu of Suppaq. ${ }^{56}$ La Makkasau, the datu of Sawitto, was also called petta Malaé. He was the first to accept Islam. ${ }^{57}$ It was Datuk ri Bandang ${ }^{58}$ who brought Islam [to South Sulawesi].

In the hikajat of Gowa and that of Wajoq it is mentioned that when the ruler of Talloq, I Mallingkeang Dg Mennjonriq and his relative the ruler of Gowa, I Mangarrangi daéng Mharaqbia, became Muslims in the year in 1605 , they spread Islam [in the region]. ${ }^{59}$ First they attacked Sawitto and Suppaq (who at that time had become Christians ${ }^{60}$ ) and defeated them so then it would be easy to defeat Sidénréng. After Sidénréng, then Soppéng, Wajoq and finally Boné [were defeated]. In the Bugis language this was called the musuq sellengngé. ${ }^{61}$

La Makkasau married in Ganra [with] the child of Pattepuang. This Pattepuang was a child of the ruler of Goa [who] was [born] because of a marriage with the child of the arung Ujung, who was called Imaria. He had two children, a boy called La Tanripeppang and a girl called Bessé Ganra. ${ }^{62}$ La Tenripeppang succeeded his father as ruler of Sawitto (his posthumous name was matinroé ri Masigiqna ${ }^{63}$ ).

When matinroé ri Masigiqna died there was a war between Sawitto and Sidénréng. This was because the aqdatuang Sidénréng wanted to become ruler of Sawitto [but] the people of Sawitto wanted the nephew of Malaé [to rule], who at that time was also the crown prince of Suppaq. The aqdatuang of Sidénréng ordered his paternal half-brother, who was called 
La Kangkong, to attack Sawitto. He died in the war and was buried close to Malaé. He was promised the kingdom if he cut off La Kuneng's head.

When La Kuneng died, he was succeeded by his daughter called andi Tanunnuq, the wife of La Wawo. ${ }^{64}$ She gave birth to daughters called andi Tanri and the other andi Makkuli. When andi Tanunnuq died she was succeeded by La Cibu, her brother. ${ }^{65}$ La Cibu married andi Mario, a person of Soppéng [who] was not an anaq mattolaé. ${ }^{66}$ Later he married again with a truly royal princess, [a daughter] of the arung Paso. She gave birth to andi Aengngang. Andi Mario was the mother of Wé Passullé, the wife of La Gau. When La Cibu died he was succeeded by andi Passulé. ${ }^{67}$ She was not an anaq sengeng ${ }^{68}$ but was known to Sawitto and it was believed [she was] destined to palorong wélareng patjolli raukkaju (weave together different generations and maintain cohesion and prosperity). ${ }^{69}$ Consequently, the Paqbaté-baté, which are Langa, Jampué, Pénrang and Tiroang, agreed with the people of Laleng Bata to make her ruler. ${ }^{70}$ When Wé Pasullé died La Gauq (her husband) replaced her. Their children were La Tammaq the splendid Sulléwatang of Sawitto and andi Baéda the present ruler [of Sawitto]. ${ }^{71}$ When La Tammaq died andi Baéda became ruler. She was the widow of La Sadapottoq, the aqdatuang Sidénréng.

\section{List of Sawitto Rulers Constructed by the Writer}

According to the information above, it seems that the succession of the Sawitto rulers is as follows: ${ }^{.72}$

1. A nobleman from Luwuq

2. The child of a manurung

3. La Mattanawali (akkadoang)

4. Daughter of La Mattanawali

5. La Pasolongi (aqdatuang)

6. The child of La Paselongi

7. La Cellaqmata

8. Torijalloq (matinroé ri Tamanroli)

9. Tanrisuji

10. La Makkasauq (Malaé). The first to become a Muslim

11. La Tanripeppang

12. La Kuneng

13. Andi Canunnuq (husband and wife)

14. La Wawo (husband and wife)

15. La Cibu

16. Wé Passullé (Not of pure royal blood) 
17. La Gauq (husband and wife)

18. andi Baéda

\section{Writer Refers to a Written Source and Revises Part of the List}

In Uwaq Dadi's lontaraq it is mentioned that matinroé ri Malaé (La Patau) was succeded by matinroé ri Sawitto, then matinroé ri Masigiqna, then matinroé ri Salemo, [then] La Toraja, [then] matinroé ri Pariamanganna who was called La Cellaq, [then] La Dokkojang was also called La Mappaq, [then] Wé Cideq, [then] La Pakkeq, then La Wawo, and after that La Kuneng.

So in my opinion those who succeeded Petta Malaé were:

11. La Batoa matinroé ri Sawitto ${ }^{73}$

12. La Tanritappu matinroé ri Masigiqna ${ }^{74}$

13. matinroé ri Salemo ${ }^{75}$

14. La Toraja

15. matinroé ri Parimanganna ${ }^{76}$

16. La Mappaq ${ }^{77}$

17. Wé Cidéq (possibly also called andi Canunnuq) ${ }^{78}$

18. La Wawo ${ }^{79}$

19. La Pakke ${ }^{80}$

20. La Kuneng ${ }^{81}$

21. $\mathrm{La} \mathrm{Cibu}^{82}$

22. Wé Passullé

23. La Gauq $^{83}$

24. La Tamma

25. andi Baéda

26. Sensi Radda [handwritten] Arug Rappang [written in Bugis script $]^{84}$

\section{Anecdotal Information}

It is possible that the petta Malaé above was another aqdatuang whose name was not given in this hikajat.

Petta Malaé had great power and married many times in Mandar, with the child of the maradia Balannipa, also with the child of the maradia of Cénrana. Her/His rule reached as far as Talle (in north Wajoq). 


\section{Recent History Relating to the 19th Century}

All of the Sawitto rulers lived in Laleng Bata until La Cibu became ruler. This was because Laleng Bata was once flooded [and] everything was destroyed. [This happened] because at the time the river Saddang still flowed through Sawitto and [a flood?] destroyed Laleng Bata, it became a river. So the ruler had to move to Cérowali. In Cérowali a mosque was built so the place Cérowali became Laleng Bata. After some time the [Cérowali] palace was burnt down and the ruler moved to Lérang-lérang and that came to be called Laleng Bata. La Cibu died and was also buried there. Wé Passullé and the ruler La Gauq also lived there. When the [Dutch] Company came then La Tamma moved to Amessangeng.

\section{Anecdotal information}

On the matter of the six brothers who had the title arung ennengngé, they had authority in the land [of Sawitto] because their sister became ruler. She also ruled in Sidénréng, Rappang, Sawitto and Énrékang. The grandchildren of the arung ennengngé had the title ulu anangngé and were also called liseqna Laleng Bata (which means, the contents of Laleng Bata). ${ }^{85}$ Their judgement was always taken when people wanted to appoint an aqdatuang, and this continues today. This is also the case when appointing a kadi. ${ }^{86}$

\section{Statement by the $h S$ 's writer}

If we consider that from the past until today there have been many people who acknowledge themselves as royalty, and their noble descendants are still present today. Their marriages and deaths must be arranged by a kadi, regardless of where they live. There are some who live in Langa, in Jampué, in Benteng and other places. A sign of them is that on the first Thursday evening of each month they burn torches on the stairs [of their houses]. ${ }^{87}$

\section{Historical Gossip}

When an aqdatuang died it was customary to keep the corpse for 100 days, during which time rituals were carried out. Meanwhile, the Paqbaté-baté, the arung Pénrang, arung Jampué, arung Langa and the arung Tiroang, would reach a consensus [on appointing a new aqdatuang] and the to ri Laleng Bata accepted their judgement. ${ }^{88}$ Today, who knows who will make any judgement for the people of Laleng Bata as it is no longer certain who will be called. ${ }^{89}$ 
When a ruler died and was buried, and his grave had been filled with earth, then the Arung Tiroang would stand in the middle and inform the people who would become [the new] ruler [but he] was often replaced by the kadi [in this role].

\section{Tradition from a manuscript source}

I also read in lontaraq from Langa: "The people of former times said, if you inaugurate an aqdatuang of Sawitto who is not descended from one of matinroé ri Mala's children then that is wrong. Even if [they are] only part person and part wood those [descended from matinroé ri Mala) can make the people of Sawitto prosper, make the vegetation grow, and see what is good. So it is only the descendants of matinroe ri Mala who can become ruler. Even if you seek [a] good [ruler] in all places below the sky [you will find none as good] as the descendants of matinroé ri Mala. It is they who you should take [as ruler]."

\section{ORALITY, WRITING, SOURCES AND HISTORY IN THE HIKAJAT SAWITTO}

The $h \mathrm{~S}$ presents an account of the past based mainly upon what the creator was told by the matoa of Depang and Uwaq Dadi. Written sources containing information about Sawitto are mentioned a number of times, and on one occasion the chronicles (referred to as hikajat) of Gowa and Wajoq are cited as sources for information on the early 17th-century wars of Islamisation. Despite the availability of written sources, some of which the writer states he has read, it is the oral data that is most copious and appears to take preference, while the written sources appear supplementary, consulted or mentioned when the oral data is insufficient. At one point, information from a manuscript owned by Andi Pawiloi that the writer indicates he has read, and would have proved correct, is ignored in favour of an oral source. This preference for first seeking information from the oral register and turning to written sources only if further material is required is common in South Sulawesi, as Koolhof (1999) has shown.

In a previous examination of the relationship between oral and written historical information, I presented a number of examples that illustrate how both oral and written material are often transmitted concurrently through the spoken word. Those people who relate such information frequently do not recall from which register it is derived. They regard such a question as unimportant, as they consider both oral and written information about the 
past to be a collective body of knowledge that can be called upon when needed (Druce 2009: 78-79). The relationship between the oral and written as depicted in the $h \mathrm{~S}$ would suggest that in this example orality was the primary medium for transmitting the past. In this context it is of note that the names given for the rulers of Gowa and Talloq who converted to Islam bear no resemblance to the names written in the sources from which the information is said to be derived. These names probably become transformed over time as the story was transmitted orally, as it is unlikely that any of the $h S^{\prime}$ s informants had read either of the two chronicles but received the information orally.

\section{The First Five Oral Traditions}

Regardless of who created it and for whatever reason, the $h \mathrm{~S}$ is a product of its time and the oral sources it presents are a window on how the past was remembered and perceived in the early 20th century. Many of these traditions appear to have been written down verbatim as there is no detectable editing, particularly the first five oral traditions presented in the text and the genealogical information that follows until the first list of rulers. Typically of South Sulawesi oral traditions about the past, they are concerned with the origins of rulers and kingdoms, relationships that establish ties and kinship links with other areas, claims relating to origin and precedence, and elite genealogies.

The order in which these traditions appear in the text, at least up to the first list of rulers, appears to be the order in which they were told, and presumably represented a basic chronological perception of the past in the minds of the informants. Perhaps it was these informants who made the rudimentary attempts to link some of these traditions when recorded for the $h \mathrm{~S}$, although it is possible this process took place earlier in their transmission and we cannot dismiss the possibility that the writer may have attempted to make the links himself. In my experience of collecting oral traditions in South Sulawesi, oral stories and genealogies are generally told as independent units. Some informants who can relate several independent traditions about a particular place will have a perception of their chronological order but rarely make any attempt to link them together as a continuous whole. Such a chronological order is not necessarily shared by other informants who know the traditions, while some may not be able to put them all in a sequence.

The second, fourth, and fifth traditions are familiar to me from research in the Sawitto region. The third tradition is unknown to me, in either oral or written form, and while stories linking Sawitto to the Toraja 
region are common, the places named in the $h \mathrm{~S}$ are not usually mentioned. Many of the names of individuals that appear in the oral genealogical information are found in written genealogies for the Ajattappareng region; others are not and there are numerous errors, particularly in the early sections. These traditions and their functions are discussed below.

The $h S$ 's opening tradition, which claims to tell of the first rulers of Sawitto, Sidénréng and Rappang, tells us nothing about the past and the reference to Luwuq simply serves to provide appropriate status for the unnamed siblings. The tradition's two functions are to explain the etymology of the kingdoms names and to set out an order of precedence between them. These relationships are conveyed through the birth order of the siblings that places Sawitto before Sidénréng. ${ }^{90}$ These two kingdoms were the largest in Ajattappareng and this concern by Sawitto for its precedence over Sidénréng (which is evident in other $h \mathrm{~S}$ traditions) suggests competition between them for leadership in the confederation. Likewise, the short fourth tradition, which is well known in the Ajattappareng region, and in several manuscripts, is concerned with an order of precedence between the kingdoms. On this occasion all five kingdoms are included with Alitta occupying the lowest level in this order, justified through a play upon its name. Most versions told outside the former territory of Sawitto contest Sawitto's claims of precedence by stating that the eldest of the brothers is the ruler of Sidénréng (Druce 2009: 166-167).

Both of these traditions probably developed after the mid-16th century, and perhaps as late as the 19th. Written genealogies and archaeological data from the Ajattappareng region show that before the mid16th century Suppaq was the most important of the five kingdoms and had precedence over Sidénréng (Druce 2009: 174). By the 19th century Suppaq's importance had declined dramatically as Sidénréng took over its tributary lands and gained control over the growing port of Parepare to the south of Suppaq.

The second tradition presented in the $h \mathrm{~S}$, telling of the seven siblings, is still known to a few people in Sawitto. A version of this tradition was recorded in a Bugis manuscript copied in 1903 (Druce 2009: 188-192). All versions are broadly similar to the one in the $h \mathrm{~S}$, in that they tell of a movement from the highlands, generally the Toraja region, to Lamadimeng by seven siblings who, after initially agreeing to aid the ruler, turn on him for breaking his word. A new dynasty is then established that creates order and stability and the youngest sibling, consistently a girl, becomes ruler of Sawitto.

This Sawitto tradition presents a contrast to the numerous other South Sulawesi traditions that serve to set out the origins and appropriate status of 
ruling families. Most of these traditions usually tell of the arrival of a tomanurung, totompoq or high status individual from another kingdom to a populated area that has no ruler. They are then subsequently invited by the people to rule them. In the Sawitto tradition there is already a ruler and it is through conquest that the new ruling dynasty is established. Historical and archaeological data shows that between the 14th to 16th centuries some highland groups did indeed move down to the Sawitto lowlands where several multi-ethnic polities developed, and until about the early to mid-16th century Sawitto appears to have been politically fragmented (Druce 2009: 151-159, 194-198). The tradition presented in the $h \mathrm{~S}$ appears to be linked to these events and probably dates to sometime before 1600, born from conflicts between different groups, some highlanders, for control of the fertile rice growing areas of central Sawitto. ${ }^{91}$

The third tradition that relates how a female ruler was taken to Randanan again connects Sawitto to the Toraja region, but on this occasion through the motif of the ruler's failure to maintain the agricultural fertility of the kingdom. The idea of a ruler's legitimacy being linked to agricultural fertility and prosperity is widespread in South Sulawesi sources. ${ }^{92}$ It is most commonly set out in traditions that tell of an agreement between the first ruler and common people, who agree to follow, obey and provide material wealth. In exchange, rulers provide prosperity, welfare and agricultural fertility. Should a ruler fail to provide these they can be deposed. ${ }^{93}$

The story of the rejection of the unnamed female ruler serves to establish kinship links between Sawitto and the Toraja region. In this story, the ruler who fails to maintain fertility and prosperity is purposefully taken to Toraja and becomes ruler of Randanan. Her two sons, presumably the result of a union with a Toraja noble, eventually become the rulers of Sawitto and Sidénréng and the new Sawitto ruler is known as "The child of the akkaqdaoang sent from Toraja." The title of the ruler used in this tradition, akkaqdaoang, does not appear in any other oral or written sources from South Sulawesi, where the title used for Sawitto rulers is aqdatuang. However, for Sidénréng the title aqdaoang is often used in oral and written sources for pre-Islamic rulers, later changing to aqdatuang after conversion to Islam. ${ }^{94}$ It is possible that akkaqdaoang is derived from a combination of the title aqdaoang and the Bugis word akka (to "lift" or "raise") that became combined during the transmission of the tradition.

The fifth tradition is well known in the Ajattappareng region; most oral versions are longer than the one in the $h \mathrm{~S}$. The tradition functions to set out the close relationship between the five kingdoms, their ruling families and the people of the respective lands. The house that is said to have been built is symbolic and represents the Ajattappareng confederation with each 
of its five parts signifying one of the five kingdoms. At the same time, the agreements that are said to have been made probably have historical bases. Given that the economy of this region was based on wet-rice agriculture it is not surprising that one agreement allows for mutual cooperation in relation to labour for rice cultivation, while emphasising that the people of the individual lands must remain loyal to their own ruler. While the $h \mathrm{~S}$ tradition claims the house was built in Sawitto, when told in other parts of Ajattappareng the location changes to either Sidénréng or Suppaq, again reflecting a concern with precedence.

\section{Genealogical Information}

Oral genealogies are widespread in many former Bugis and Makasar polities today. The one attached to the tradition of the Ajattappareng house, supplemented by written sources, contains more details that one finds in twenty-first century examples ${ }^{95}$ but nevertheless highlights the fact that detailed and reliable genealogical information in South Sulawesi lies firmly in the written register. ${ }^{96}$ As Vansina (1985: 24) points out, cumulative traditions (as opposed to interpretive traditions, such as origin stories) "do not fare well in memory." While many of the names given in the $h S^{\prime} s$ genealogy can be found in written genealogies, there are numerous omissions, mistakes and confusion with individuals placed in the wrong order. The creator attempts to rectify some omissions through consultation of a written source but the problems of identifying some individuals from posthumous names alone adds to the confusion and the written source used appears unreliable. Interestingly, the creator does not use this written source to revise the genealogy of the pre-Islamic names, where numerous errors are found.

The first two names from the pre-Islamic period to appear in the genealogy are Cellaqmata and I Jépo (correctly Gémpo), both of whom consistently appear in written genealogies and can be dated to the mid-16th century. However, a number of names and other information given for the generations that follow are difficult to reconcile with written genealogies. Some individuals also appear to have been known in the oral register by a name that is different to that of the written. These individuals can be identified through careful reading of the genealogies. An example is the confusion surrounding Cellaqmata's successor as ruler of Sawitto. The $h S^{\prime}$ 's oral version gives his name as Torijallo but Andi Pawiloi's lontaraq states that it was La Pancai. All written Ajattappareng genealogies name La Pancai as Cellaqmata's son and successor and inform that he was known as Témmaruling. La Pancai and Torijallo are, however, the same person: 
Torijallo means "the one who died in amok" and, according to written genealogies, this was how La Pancai died (yia namaté rijallo). Torijallo is never given as a posthumous name for La Pancai in any written source but it appears that this is the name he was remembered by in the oral register.

The information concerning Torijallo's descendants is, in places, confused. While the $h \mathrm{~S}$ is correct in stating that his daughter married To Pataka of Wajoq, her name was Wé Pasullé, not Tanrisuji. The Tanrisuji named in the $h \mathrm{~S}$ was perhaps one of Wé Pasullés children. ${ }^{97}$ Wé Pasullé herself, who does not appear in the $h \mathrm{~S},{ }^{98}$ was also the first ruler to convert to Islam and written genealogies inform us that she was known by two other names, datu Bissu and posthumously, matinroé ri mala (she who lies in a grave: an early convert to Islam who was buried rather than cremated). The male La Makkasau who the $h \mathrm{~S}$ incorrectly tells us was the first ruler to convert to Islam was in fact Wé Pasullé's grandson and Sawitto's third Muslim ruler. A form of Wé Pasullés posthumous name appears to have been retained in this oral tradition and to have become connected to $\mathrm{La}$ Makkasau. The $h \mathrm{~S}$ also states that La Makkasau was known as Petta Malaé ("the lord/lady who has a grave"). ${ }^{99}$

\section{Gossip and Modern History}

The $h \mathrm{~S}$ also contains historical gossip and recent history. Historical gossip can be traditions in the form of hearsay that continue to be transmitted because societies find them of interest. Most are short accounts that serve no political or ideological function and are likely to be derived from actual events. One example of historical gossip from the $h \mathrm{~S}$ is the information concerning the corpse of a deceased ruler that was formerly kept for 100 days before burial, during which time rituals were carried out. This information surely dates back to the pre-Islamic period when the corpse was placed in a wooden coffin-like structure with a tube inserted to drain off the body fluids until the bones remained, as described by the mid-16th century Portuguese trader Antonio de Pavia (Baker 2005: 78). This method continues to be practiced by some Toraja people. After decomposition, the remains would have been cremated.

Recent history related in the $h \mathrm{~S}$ concerns the flood that destroyed Sawitto's palace centre and the subsequent movements of the palace when La Cibu ruled in the mid-19th century. The $h \mathrm{~S}$ also informs us several times that the River Saddang had changed its course, an event that dates to about 1890 (Druce 2009: 117-118) and which informants may have lived through. A little less reliable is some of the information concerning the war between Sawitto and Sidénréng that took place towards the end of the 18th or the 
beginning of the 19th century, waged by the Sidénréng ruler La Wawo. According to Mukhlis et al. (1985: 101), La Wawo was attempting to place his son, Muhammad Petta Cambangnge, on the Sawitto throne, not his halfbrother, and it was Muhammad Petta Cambangnge who died in the war.

\section{CONCLUSION}

Historians who have used one or more of the four 17th-century Bugis and Makasar chronicles to write South Sulawesi's past may be dismissive of the $h \mathrm{~S}$ as a historical source, and even regard it as atypical. It tells us little about the expansion and development of the kingdom, and while some of the stories may be derived from historical events or situations, they are presented in a quite different form to the sober refined and edited accounts found in the chronicles that were purposefully placed in a framework based on Portuguese models. Likewise, the genealogical data is unreliable and too problematic to establish dynastic lists or chronologies. Other historians, however, will perhaps recognise the $h \mathrm{~S}$, or rather the sources that were used to create it, as familiar in that these sources resemble the majority Bugis and Makasar historical writings found in manuscript form and reflect oral traditions that were frozen in writing at various points in the past. Such traditions are most representative of South Sulawesi historical writing and it is conspicuous that the few long written historical compositions that date to before Indonesian independence can be traced to European influence: the Portuguese in the 17th century, the Dutch in the 18th and 19th centuries and again, in the first few decades of the 20th century, with the writing of the $h \mathrm{~S}$. In this context it is worth noting B. F. Matthes' quest for a complete, full-length version of the La Galigo epic, and his frustration in finding only what he considered to be fragments (Matthes 1872: 250-251). To his 19thcentury European mind, the existence of a complete version of this story, from which he believed such fragments must be derived, was a logical assumption. A complete version, however, had never existed as it is a tradition of poetic story-telling and not a single work. Matthes eventually turned to Colliq Pujié, who, at his request, duly produced twelve volumes of the La Galigo that have often been misunderstood as a complete version of this tradition.

Perhaps the striking insight that the $h S$ provides on how the past was remembered and transmitted is that so few of the sources used in its creation were written, and that even when written sources were used they appear to have been considered less important than oral sources. This is all the more salient when we consider that writing in South Sulawesi developed about 
500 years before the $h S^{\prime}$ s creation, but, despite the long history of writing, orality still prevailed as the primary medium for recalling the past. There was no watershed in the relationship between orality and writing in Bugis and Makasar society and the Great-Divide theories proposed by Goody and Watt (1968), Goody (1987), Ong (1982) and others that present orality and writing as a dichotomy appear wholly inappropriate for the region. We should, however, remain mindful of the fact that despite the major contrasts in style, structure and length between the chronicles and the more typical orally derived works, they remain the products of the Austronesian societies that produced them. As such, they collectively share fundamental Austronesian concerns about the past, namely origin, precedence, the ruling elite, and status.

\section{APPENDIX}

\section{Hikajat Sawitto}

\section{Jang saja dengar pada Matowa Depang dan Owa' Dadi}

[page 1] Pada zaman dahoeloe kala adalah tiga toeroenan radja dari Loewoe tiga bersaudara, masing-masing mempoenjai aratoes ${ }^{100}$ hamba sahaja; radja itoe toeroenan dari padjoeng di Loewoe. Waktoe itoe di Sidénréng, di Rappang dan di Sawitto didiami manoesia djoega tetapi beloem ada radjanja. Djadilah ketiga radja berdjalan-djalan pergi ketempat itoe, alnggahlah ${ }^{101}$ di Sidénréng, bertanjalah jang tiga itoe, ${ }^{\text {a } a p a k a h ~ j a n g ~ p a n d j a n g ~}$ itoe. $^{\text {a102 }}$ Djawab orang disitoe: "Itoelah "koeli-koeli sidénréng." "Kalau begitoe tempat ini koenamailah 'Sidénréng,' baiklah jang tengah menjadi radja disini." Serta tempat itoe dinamainja Sidénréng (Koeli-koeli kaleleng ${ }^{103}$ ).

Setelah itoe maka kedoeanjapoen berdjalan poela; didapatnja soengai di Rappang, sampah bertimboen $\mathrm{si}^{104}$ soengai itoe. Bertanjalah kepada orang, ${ }^{b}$ apakah jang bertimboen didalam soengai itu. ${ }^{\text {b105 }}$ Djawab orang disitoe: "itoelah dimanai ${ }^{106}$ 'rappang' dialah." Djawa ${ }^{107}$ anak radja itu: "Djika begitoe baiklah negerimoe ia dinamai "Rappang." Tinggallah jang boengsoe djadi radja sisitoe. ${ }^{108}$ Jang soeloeng itoe pergilah kebarat; sampailah keseboeah tanah, didapatlah ia soeatoe pohon jang besar. Bertanjalah ia kepada orang-orang, " pohon apakah itoe. ${ }^{\text {c109 }}$ Djawab orang jang ada ditempat itoe: "Itoelah bernama 'sawitto'." Maka iapoen singgallah ${ }^{110}$ disitoe serta negeri itoe dinamainjalah "Sawitto." Maka djadilah tiga bersaoedara itoepoen djadilah radja di Sawitto, Sidénréng dan Rappang. 
Pada waktoe itoe, orang Pallataoeng, ${ }^{111}$ orang Anak Banoea, pendeknja orang disebelah barat Sa'dang (Sa'dang waktoe itoe djalannja lain) artinja negeri-negeri jang disebelah barat soengai, tiada hendak menoeroet perintahnja.

Pada masa itoe adalah timboel (tiahoel ${ }^{112}$ ) dihoeloe soengai (Sa'dang) seorang lelaki. Cabarnja (Chaharaja ${ }^{113}$ ) radja di Sangalla' bermimpi ada pada soeatoe hari kelihatan sepotong (saparanjang) [page 2] pettoeng ${ }^{114}$ (bamboe) mengalir keoedik, aroeng Sangalla' toeroenlah kesoengai, dilihatnjalah tellang ${ }^{115}$ itoe, laloe ${ }^{\mathrm{d}}$ gaoe' datoe ${ }^{\mathrm{d} 116}$ semoea diboenjikan, dibawanja ke istana. Sampai anak laki-laki, maka diambilkannjalah ${ }^{{ }^{i}}$ toe soesoe ${ }^{\mathrm{e} 117}$ doea kali sembilan.

Tiada berapa hari kemoedian bermimpi poela isterri ${ }^{118}$ radja Sangalla', ada orang berbitjara dengan dia katanja: "Esok hari kamoe berdjoempa seboeah boesah $\left(\right.$ boelah $^{119}$ ) air mengalir keoedik, ambillah boesah air itoe bawa keistana. "Pada keesokan harinja isreri ${ }^{120}$ radja itoe pergilah kesoengai, didapatnjalah boesah air itoe, dibawanjalah keistana, dengan tjara kehormatan. Setelah itoe boesah air itoe dibelahkan, keloearlah seorang anak perempoean, laloe ditjaharikan djoega doea kali sembilan iboe soesoe.

Setelah soedah besarlah kedoeanja jang lalaki bolehlah beristeri dan jang perempoean bolehlah bersoeami, maka kedoeanja dinikahkanlah (tjara dahoeloe).

Atas perkawinan ini terdjadilah 8 anak, jang soeloeng dan jang boengsoe perempoean. Maka jang soeloenglah bersoeami di oeloe Sa'dang, ialah djadi neneknja radja di Enrekang dan Aroeng Batoelappa.

Berkatalah Tomanoeroeng itoe: "Anak kita jang soeloeng itoe adalah tempatnya, anak kita jang toedjoeh itoe kemanalah perginja, dinamalah kita simpan?" Oedjar jang lai-laki itoe: "Adalah negeri disebelah sebelah selatan tanah ini bernama Sawitto, baiklah kita soeroeh ketoedjoenja pergi kesitoe. Ada seboeah kampoeng namanja Lamadingeng, baiklah soeroeh kesitoe, disitoelah ia soeroeh berkebun." Maka ketoedjoehnja pergilah ke Lamadingeng. Ia bertemanlah teboe, keladi, pisang dan lain-lain.

Pada soeatoe hari pergilah kepasar mendjual teboenja, maka disanalah ia bertjakap-tjakap dengan hamba radja, katanja: Saban hari kami berperang sadja, habis Malimpong Talabangi lagi jang melawan. Kata orang itoe $^{121}$ : "Kalau radja akan anoegarahkan ${ }^{122}$ kepada kami berang ${ }^{123}$ jang kami ingin, kita sanggoep akan melawan moesoeh radja itoe." Maka tiba-tiba pada [page 3] soeatoe hari ia dilihat radja. Maka kata radja: "Siapakah orang mendjoeal teboe itoe, lain benar roepanja." Kata orang: "Orang itoe asal dari goenoeng, dia ada tinggal di Lamadingeng berkeboen, toeankoe; ia terlaloe sombong mengakoe melawan moesoe ${ }^{124}$ toeankoe." Radja itoe soeroeh panggil orang itoe nail ${ }^{125}$ leistana. ${ }^{126}$ Setelah orang itoe sampai keistana, 
maka radjapoen bertjakap-tjakap dengan dia sehingga ia mentjeritakan "Adapoen orang Palleteang itoe tidak boleh koetoendoekkan, ia tidak maoe toeroet perintahkoe." Djawabnja: "Kami sanggoep menoendoekkan orang Palleteang itoe sampai ohidmat ${ }^{127}$ kepada radja." "Baiklah," kata radja. "Kalau engkau boleh menaloekkan ${ }^{128}$ orang Palleteang ${ }^{129}$ itoe, engkau koeberi pangkat di Sawitto ono, ${ }^{130}$ serta "elo'moe koewa adamoe tongeng ritanae ri Sawitto" (artinja kehendakmoe berlakoe perkataanmoe jang bensar $\left.{ }^{131}\right) . "$

Setelah itoe maka toeroenlah kepasar lagi orang itoe, ${ }^{132}$ laloe teboenja diberikan sadja kepada orang lain, laloe poelang keroemahnja. Sampai keroemahnja ia tjeriterkan kepada saudaranja, katanja: "Tjelaka kita ini, kita disoeroeh radja akan memerangi orang jang enggan toeroet perintahnja." Kata saudaranja: "Baiklah, boekanlah kita poenja emak-bapak memang asal orang dari kajangan?" Pendeknja ia bersediahlah tiga bersaudara berperang dengan Palleteang; ${ }^{133}$ Palleteang itoepoen dialahkannja, demikian djoega Lampangeng, Boeloe dan Salo, laloe ia kembali keroemahnja. Tiga yang lain poela pergi memerangi Poso' $\left(\mathrm{Peso}^{\prime 134}\right.$ ), Boeloe, ${ }^{135}$ Sekkang dan Boea, laloe kembali keroemahnja. Jang lain poela pergi memerangi Madallo, Paria, Tjempa dan Tampia laloe kembali keroemahnja. Tiga jang lain lagi mengalahkan Padangkalawa, Ka'ba dan Poennia, maka djadilah semoa dialahkannja.

Setelah itoe ditoenggoehnjalah kasihan radja, tiada djoega datang. Djika radja sedang doedoek didjendala menindjau maka laloe anak manoeroeng itoe, ia toetoep djendelanja itoe. Setelah lamalah ia me [page 4] noenggoe pembalasan radja seperti soedah didjandjikan itoe maka tiada djoega dipenoehinja, pergilah mengadjak orang Palletenng ${ }^{136}$ akan membalas hati djahat radja itoe. Maka djadilah perang Sawitto dengan orang Palleteang dan anak manoeroeng itoe. Radjapoen larilah pergi ke Belokka. Maka anak manoeroeng itoe moefakatlah dengan lain-lain orang mengangkat anaknja manoeroeng itoe jang perempoean itoe mendjadi radja, serta saudaranja jang lain itoe bergelar ${ }^{f}$ aroeng ennengnge ${ }^{\mathrm{fl} 37}$; ia berkoeasalah di Sawitto, Sidénréng, Rappang karena diwaktoe itoe tidak ada djoega radjanja.

Kepala Sempang berkata: "Ketika radja diperangi oleh orang Palleteang dengan anak manoeroeng itoe pergilah ke Rappang dia disoedoel ${ }^{138}$ kesitoe, bersama saudaranja lari ke Sidénréng, disanapoen ia disoesoel hingga lari ketiganja pergi Loewoe kembali. ${ }^{13}$

Entah berapa lamanja radja perempoen itoe kawin dengan radja Loewoe maka mendapat anak seorang bergelar Lamattanawa(e)li: ialah mendjadi radja di Sawitto, Rappang dan Sidénréng serta bergelar "Akka'daoangnge." Adapoen Lamattanawa(e)li ini ada anaknja seorang 
perempoean, ialah diperisterikan oleh Aroeng Oedjoeng di Soppeng; ialah jang menggantikan ajahnja djadi Akkadaoang di Sawitto, Rappang dan di Sidénréng.

Pada waktoe dia djadi Akka'daoang di Sawitto itoe maka padi tidak djadi; segala boeah-boeahhanpoen ${ }^{140}$ tidak berboeah. Maka moefakatlah orang Sawitto, Rappang dan Sidénréng hendak menoeroenkan radjanja; diboeatnja oesoengan laloe dioesoengnja ketanah Toradja dinegeri jang bernama Randanan; ia letakkan ditengah-tengah padang, maka ia tinggalkan disitoe. Orang Randananpoen memoengoet radja itoe serta didjadikan radjanja karena ia " ${ }^{\text {"ma'dara takkoe" }}{ }^{\text {g141 }}$.

Orang Sawitto kembalilah ke Sawitto; habislah tanaman djadi kering, binatang poen habislah mati, hanja di Rappang ada kelihatan daoen jang hidjau. Soesahlah hati orang Sawitto.

[page 5] Tiada berapa lamanja terdengarlah oleh orang Sawitto bahwa radja jang soedah dia bawa itoe ke Toradja ada melahirkan doea orang anak lelaki, jang soeloeng bernama Lepasalongi, jang boengsoe bernama Lamattambero. Pergilah orang Sawitto dan orang Sidénréng ketanah Toradja akan mentjari Akka'daoang itoe, maka didapatinjalah di Randanan. Maka dipintanjalah ${ }^{142}$ anaknja itoe akan didjadikan radja di Sawitto dan di Sidénréng. Ketika anaknja itoe diminta ia tidak berikan, ia tinggalkan Randanan laloe pergi ke Makale. Orang Sawitto dan orang Sidénréng poen kembalilah. Entah berapa lamanja kembali poela orang Sawitto dengan orang Sidénréng ke Tana Toradja akan minta kedoea anak itoe soepaja didjadikan radja. Sahoet iboenja: "Hai kamoe orang Sawitto dan orang Sidénréng, bahwa antara kamoe itoe tentoe ada djoega jang mempoenjai anak doe ${ }^{143}$; soekahkah joega kamoe ditjeraikan dengan anakmoa itoe? Baiklah kamoe poelang sadja kenegerimoe." Orang Sawitto dan orang Sidénréng kembalinja kenegerinja.

Tiada berapa lama kemoedian daripada itoe orang Sawitto dengan orang Sidénréng bermoefakat lagi akan pergi ke Randanan; dibawanja djoega banjak orang perempoean pergi ke Randanan lagi. Setelah mereka itoe sampai ke Randanan, maka bekau ${ }^{144}$ Akkta'daoangnge berkata: "Baiklah kembali sadja kamu sekalian, djika ditakdirkan dewata sadja melihat negerimoe, niatjaja ${ }^{145}$ sajapoen ada joega kesitoe." Setelah itoe orang Sawitto dan orang Sidénréng kembalilah menoenggoe-noenggoe datangnja radja itoe.

Entah berapa lama, ia kirimkanlah anaknja kedoeanja, jang soeloeng jang bernama Lapasalong ia diradjakan di Sawitto serta jang boengsoe jang bernama Lammattambero ialah djadi radja di Sidénréng. Maka orang banjak bertanjalah nama sendirinja, siapakah jang didjadikan radja itoe. Maka djawab orang: "Ana'namoea Akka'daoangnge na'de atoeang pole ri 
Toradja," artinja "anaknja djoega Akka'daoangnge dikirimkan dari Toradja." Dari sebab itoelah roemahnja dinamai "sao-radja" serta dia sendiri moelai waktoe itoe diseboet "Toria'deatoeangngeeanja, kemoedian ber [page 6] gelar "A'deatoeangnge."

Itoelah waktoe bermoela radja di Sidénréng dan Sawitto bergelar "A'deatoeng."

Kemoedian daripada itoe, berpesan bekas Akka'daoangnge itoe kepada anaknja: "kalau kamoe hendak mentjahari familimoe ke Toradja, engkau ke Randanan, ke Makale dank $\mathrm{e}^{146}$ Batoe sadja, dan kalau engkau lahirkan anak maka seorang lelaki jang lain perempoean engkau kawinkan". Kemoedian jang di Sidénréng itoe melahirkan seorang lelaki, dan jang di Sawitto itoe melahirkan perempoean. Djadilah dikawinkan.

Daripada perkawinan ini djadilah empat anak laki-laki. Jang soeloeng djadi radja di Sawitto adiknja mendjadi radja di Sidénréng, adiknja lagi djadi radja di Rappang serta jang boengsoe djadi radja di Soeppa.

Kemoedian beranak lagi seorang lelaki, tidak ada tanah jang akan diperintahnja. Tiada lama kemoedian daripada itoe adalah negeri dikaki goenoeng jang bernama "Pa'bola batoewe," ditaroehlah anak jang kemoedian djadi itoe mendjadi raja disitoe. Dimanailah "Petta Pa'bola batoewe." Entah berapa lama datanglah radja Soeppa kepada kakaknja laloe bertanja: "Apa kerdja adik kita $\left(\right.$ anritta $\left.^{147}\right)$ : Sahoet radja "Apa jang akan dikerdjakan, pada hal dia seorang anak jang moeda sekali." "Kalau begitu baiklah negeri itoe kita seboet 'Alitta' (arintta)." 148

Setelah itoe radja memboeatlah roemah di Sawitto lima roeang masing-masing roeang adalah biliknja, tempo-tempo adalah berkoempal lima saudara itoe di Sawitto disanalah ia tinggal, dan disanalah ia berdjandji lima bersaudara:

"Temma'bola sielle' (artinja: berroemah ${ }^{149}$ tidak berantara), sioema(n) siliweng (artinya: boleh bersawah didaerahnja jang lain), tessikadja lempong-lempong (artinja: tidak boleh menangkap ikan didalam tempat ikannja masing-masing), wesse ase mappamasa (artinja: masing-masing ra'jat berbakti kepada radjanja sendiri)."

Maka jang djadi radja di Sawitto otoe ${ }^{150}$ mendjadi [page 7] kan anak doea orang, seorang lelaki dan seorang perempoean, jang lelaki bernama Tjella'mata yang perempoen bernama I-Djepo; si Djepo ini kawin dengan anak Adeatoeang di Sidénréng bernama Baso'Massepe. Si Tjella'mata djadi radja di Sawitto, dia beranak lagi bernama Toridjallo (Matinrowe ri Maro $\left.{ }^{151}\right)$. 
152"Di dalam lontara pabitjara Andi Pawiloi ada "saja batja bahwa seorang Datoe di Soeppa memper-"toenangan anaknja jang bernama Lampa'weloe ${ }^{153}$ maka "tidak didjadikan karena Adeatoeang di Sawitto hen"dak mengawinkan Latjella'mata itoe dengan Lampe'weoela maka djadilah ragja $^{154}$ Gowa Toenipalangga sangat marah maka djadi perang antara Sawitto dengan Gowa; toedjoeh kali Gowa mendatangi Sawitto baroe dialakkannja, maka diambillah Lampe'weloea (different spelling) itoe oleh radja Gowa dibawanja ke Gowa disiksa kemoedian Lapantjai didjadikan radja di Sawitto.

Siapa Lapantjai itoe tidak diseboetkan, berangkali Latjella'mata djoega.

Toridjallo itoelah beristerikan anak Adeatoeang Sidénréng jang bernama Tanroele'. Toridjallo itoelah beranak seorang perempoean bernama Tanrisoedj, ialah diperisterikan Tjakkaridi di Wadjo jang bernama Topatakka. Tanrisoedji itoepoen djadi Adeatoeang di Sawitto dan ia datoe poela di Soeppa, ialah empat anaknja, doea perempoean dan doea laki-laki. Jang laki-lakilah, jang soeloeng bernama Lamakkasaoe jang kemoedian djadi Adeatoeang di Sawitto, dan jang perempoean yang bernama Daeng Seo ialah djadi radja di Patombong Makoering (kemoedian dinamai Langa) serta jang lelaki jang lain ialah bernama Lapatombongi Datoe di Soeppa. Lamakkassoe $^{155}$ Datoe di Sawitto, ia djoega bernama Petta Malae. Ialah bermoela memeloek igama ${ }^{156}(\mathrm{SM})$ Islam. Datoek ri Bandand ${ }^{157}$ jang memasoekkan Islam.

Didalam hikayat Gowa dan Wadjo ada terseboet bahwa ketika radja Tallo I Mallingkeang Dg. Mennjonri', bersama saudaranja radja Gowa I Mangarrangi Dg. Mhara'bia pada tahoen 1605 masoek igama Islam, maka ia mengembangkan igama Islam itoe; pertama-tama di [page 8] serangnja Sawitto dan Soeppa (jang waktoe itoe soedah memaloek igama Christen) dan dialahkan soepaja gampang mengalahkan Sidénréng. Kemoedian Sidénréng, laoe Soppeng, Kemoedian Wadjo achirnja Bone. Ialah disebut dalam bahasa Bugis "moesoe' sellengnge."

Lamakkasaoe itoe beristeri di Ganra anaknja pattepoeang; Pattepoeang ini anak radja Gowa jang djadi karena kawin dengan anak aroeng oedjoeng jang bernama Imaria. Ialah melahirkan doea orang anak, seorang laki-laki bernama Latanripeppang dan seorang perempoean bernama Besse Ganra. Latenripeppanglah mengganti bapanja djadi radja di Sawitto (nama matinja bernama Matinrowe ri Masigi'na).

Ketika Matinrowe ri Masigi'na meninggal doenia, berperanglah Sawitto dengan Sidénréng, sebab Adeatoeang Sidénréng hendak mendjadi radja di Sawitto, orang Sawitto hendak mengankat kemanakan Malae, jang pada waktoe itoe radja moeda di Soeppa. Jang disoeroeh oleh Adeatoeang 
Sidénréng memerangi Sawitto itoe saudara (boekan saudara kandoengnja) yang bernama Lakangkong, ia mato ${ }^{158}$ didalam peperangan, maka ia dikoeboerkan dekat Malae djoega. Ia berdjandji memberikan keradjaan djika ia pangga ${ }^{159}$ kepala Lakoeneng.

Ketika Lakoeneng meninggal doenia, ia diganti oleh anaknja jang bernama Andi Tanoennoe' isteri Lawawo, ialah beranakkan perempuan jang bernama Andi Tanri dan Andi Makkoeli. Ketika Andi Tanoennoe' meninggal dunia digantilah oleh Latjiboe, saudara lelaki Andi Tjanoennoe'. Latjiboe beristerikan Andi Mario, orang Soppeng boekan anak mattole, ${ }^{160}$ kemoedian ia peristerikan lagi anak gahara dari Aroeng Paso, ialah jang beranakkan Andi Aengngang. Andi Mario ialah iboe dati ${ }^{161}$ Wepassoelle isteri Lagaoe. Ketika Latjiboe meninggal ia diganti oleh Andi Passoelle, boekannja anak sengeng ${ }^{162}$ tetapi ia rapat di Sawitto, serta ia dipandang bakal palorong welareng pattbili(l) raoekkadjoe (bakal mentjahatikan ${ }^{163}$ kebaikan Sawitto), dari sebab itoe maka pa'bate-bate, [page 9] jaitoe Langa, Djampoee, Penrang dan Tiroang, moefakat denngan ${ }^{164}$ orang Lalengbata mengankat dia djadi radja. Ketika We Passoelle meninggal maka Lagaoe mendjadi gentinja ${ }^{165}$ (soeaminja) ialah beranakkan Latamma' djah Soellewatang Sawitto sekarang, dengan Andi Baeda radja jang sekarang ini. Ketika Latamma' meninggal Andi Saeda ${ }^{166}$ didjadikan radja djanda Adatoeang Sidénréng Lasadapotto'.

Menoeroet keterangan jang terseboet diatas ini njatalah jang bertoeroet-toeroet djadi radja di Sawitto itoe ialah:

1. Seorang bangsawan dari Loewoe

2. Anak manoeroeng

3. Lamattanawali (Akkadsoangnge)

4. Anak perempoean Lamattanawali

5. Lapasolongi (Adeatoeang)

6. Anak Lapaselongi

7. Latjella mata

8. Toridjallo' (Marinrowe ri Tamanroli)

9. Tanrisoedji

10. Lamakkasaoe' (Malae) moelai masoek Islam

11. Latanripeppang

12. Lakoeneng

13. Andi Tjanoennoe'

14. Lawawo

\} - laki bini

15. Latjiboe

16. We Passoelle

17. Lagaoe

\}- laki bini

\} - (boekan anak sengeng)

\} - laki bini 


\section{Andi Baeda.}

Didalam lonrara Oewa Dadi' ada terseboet bahwa Matinrowe ri Malae (Lapataoe) diganti oleh Matinrowe ri Sawitto, baharoe Matinrowe ri Masigi'na, bahroe Matinrowe ri Salemo, Latoradja, Matinrowe ri Pariamanganna jang bernama Latjella, Ladokkojang djoega bernama Lamappa, Wetjide', Lapakke', baroe Lawowo kemoedian Lakoeneng. Djadi pada hemat saja jang mengganti Petta Malae jaitoe:

\section{Labatowa Matinrowe ri Sawitto [page 10]}

12. Latanritappoe Marinrowe ri Masigi'na

13. Matinrowe ri Salemo

14. Latoradjang

15. Marinrowe ri Parimanganna

16. Lamappa'

17. Wetjide (barangkali ini bernama Andi Tjanoennoe')

18. Lawawo

19. Lapkke

20. Lakoeneng

21. Latjiboe

22. Wepassoelle

23. Lagaoe

24. Latamma

25. Andi Baeda

26. Sensi Radda [hand written] Arung Rappeng [written in Bugis script]

Barangkali diatas Petta Malae ada lagi A'daetoeang jang tidak diseboet namanja didalam hikayat ini.

Petta Malae itoe amat besar koeasanja, ia banjak kali kawin di Mandar, ia kawin dengan anaknja Maradia Balannipa, dia kawin dengan djoega dengan anaknja Maradia Tjenrana. Perintahnja sampai ke Talle (Noord-Wadjo).

Segala radja-radja di Sawitto selaloe tinggal didalam Laleng-bata, hingga katjiboe ${ }^{167}$ djadi radja, karena Laleng-baata ${ }^{168}$ itoe pada soeatoe masa kebandjiran, semoeanja sebba ${ }^{169}$ roesak. Karena soenggai Sadang waktoe itoe masih jalan di Sawitto. Pada waktoe itoe Laleng-bata habis djadi soenggai, maka radjapoen pindahlah ke Tjerowali, di Tjerowali didirikan mesdjid maka djadilah di Tjerowali diseboet Laleng-bata. Entah berapa lamanja istana itoepoen terbakar, pindahlah radja pada kampoeng Lerang-Lerang, disitoepoen dinamai Laleng-bata djoega. Latjiboe ada meninggal disitoe dan dikoeboerkan disitoe djoega. We Pasoelle dan radja 
Lagaoe masih tinggal disitoe djoega. Latamma ketika kompani datang baharoe berpindah ke Amessangeng.

[page 11] Dari hal keenam saudara itoe bergelarlah "aroeng ennengnge" 170 ia koeasa didalam negeri sebab saudaranja djadi radja, ia koeasa poela di Sidénréng, Rappang, Sawitto dan Enrekang. Anak tjoetjoe "aroeng ennengnge" itoe bergelar "oeloe anangnge," dinamai "lise'na laleng-bata" (artinja isinja Laleng-bata). Ia selaloe diambil timbanganja kalau orang hendak mengambil Aeatoeang, ${ }^{172}$ sampai sekarang ini. Demikian djoega mengambil kali.

Djika dipikir dari dahoeloe sampai sekarang berapa banjak orang jang mengakoe dirinja orang ri Laleng-bata, sebab toeroenan itoe moelia adanja. Nikah dan matinja mereka itoe haroes dioeroes oleh kali, walaupeon ia tinggal dimana, karena adalah jang tinggal di Langa, di Djampoee, di Benteng dan lain-lainnja.

Soeatoe tanda bagi mereka itoe, tiap-tiap malam Djoemat pertama dari tiap-tiap boelan, dibakarnja soeloeh pada tangganja.

Apabila A'deatoeang meninggal biasa disimpan mejatnya 100 hari, selamanja diboeat oepatjara disitoe. Maka sementara itoe doedoeklah pa'bate-bate itoe moefakat, jaitoe Aroeng Penrang, Aroeng Djampoee, Arowng Langa dan Aroeng Tiroang dan diambil timbamgan tori ${ }^{173}$ Lalengbata itoe. Sekarang soedah kiranja mengambil timbangan orang ri Lalengbata itoe, karena tidak tentoe lagi siapakah jang akan dipanggil.

Apabila radja jang meninggal itoe moedah dikoeboerkan, dan koeboernja ditimboen dengan tanah, setelah bertengah berdiri Aroeng Tiroang memberi chabar (chahar) kepada ra'jat bahwa sipoelanlah (Probably pulan=fulan sifulan=so and so) mendjadi radja, biasa diganti oleh kali.

Saja membatja poela dalam lontar dari Langa: "Makkedatopi toriolowe narekko tto'doko A'datoeang ri Sawitto natania welarenna eppona Matinrowe ri Mala, selaitoe to'do'moe, namaoe nasipolomoea taoe nasepolo adjoe, naia maka pa'daoengngi raoekkadjoenna to Sawitto palorongngi walarenna paitaiwi detjeng, [page 12] nawelarennamoea Matinroe ri Mala, to'do'nisa aroeng, namaoe risaliweng langi moelolongeng maka ppedetjongiekko nawelerennamoen Matinrowe ri Mala toedjoe moeitoe aralammoe ..."

Artinja: "Kata orang dahoeloe kala djika engkau mengangkat A'datoeang di Sawitto maka boekan toeroenan anak tjoetjoe dari Matinrowe ri Mala, salah itoe, walaupoen hanja sepotong orang dan sepotong kajoem ${ }^{174}$ maka ia boleh mendjadiakn berdaoen orang Sawitto, dan mendjadikan mendjalar welarengnja serta, melihat kebaikannja, maka toeroenannja sadja Marinrowe ri Mala, djadiakn radja. Meskipoen diloear mangit engkau dapat 
jang boleh mentjarikan kebaikan maka toeroenan Matinrowe ri Mala benar itoe djoega pengambilmoe..."

\section{ENDNOTES}

* Stephen Druce obtained his PhD in Southeast Asian history from the Centre for South-East Asian Studies, Hull University. He has published international articles and book chapters on the history, archaeology and literature of South Sulawesi and early Borneo. He is the author of The Lands West of the lakes: A History of the Ajattappareng Kingdoms of South Sulawesi 1200 to 1600 CE (KITLV Press, 2009) and Sebuah Sejarah Sulawesi Selatan dan Tradisi Lisan dan Tulisan, Abad ke-13 hingga ke-17 (Penerbit Ombak and KITLV Jakarta, in press). He currently teaches Southeast Asian and Brunei history at Universiti Brunei Darussalam, where he is Programme Leader in Graduate Studies and Research in the Academy of Brunei Studies.

1 I would like to thank Ian Caldwell for his helpful criticisms and informative comments on earlier drafts of this paper. Muhlis Hadrawi corrected several of my errors in the transcription of Bugis sentences.

2 Makasar (with one "s") refers to the ethnic group of that name and their language; Makassar refers to the historical kingdom and the capital of South Sulawesi, formerly Ujung Pandang.

3 Other genres of writing about the past that lie outside the scope of this article are royal diaries that were kept by rulers and high officials from the 17th century, and historical poems dating from the 17th century, such as toloq (Bugis) and sinriliq (Makasar). The word matoa is Bugis and means headman.

4 The $h \mathrm{~S}$ is the second manuscript of microfilm roll 2, as set out in the catalogue compiled by Paeni et al. (2003).

5 This orthography was first published in 1901 and based on Dutch spelling conventions. This system was revised in 1947 and again in 1972 (Sneddon 2003: 91, $116,128)$. One notable divergence to the Van Ophuijsen system in the $h \mathrm{~S}$ is the absence of a diactritic over the schwa vowel "e," perhaps because the text was typed.

6 The four other kingdoms are Sidénréng, Suppaq, Rappang and Alitta.

7 Most codices are in the form of bound European books of generally 200 or 300 pages in length.

8 A chronicle is defined as a chronological account of past events that took place under successive rulers. Only a small number of South Sulawesi works about the past fit such a description and are discussed below.

9 Some of these attoriolong and patturioloang texts can be as short as two or three lines, while a few can reach ten pages or more in length.

10 Indonesian, English or Dutch translations of these chronicles can be found in the following: Gowa (Wolhoff and Abdurrahim 1959; Cummings 2007), Talloq (Rahim and Borahima 1975; Cummings 2007), Wajoq (Noorduyn 1955) and Boné (Macknight and Mukhlis n.d.).

11 Genealogies are discussed in detail by Caldwell and Wellen in the following paper.

12 By comparison, the various copies of the 17 th century chronicles rarely exceed 20 pages. 
13 The writer is said to have been La Sangajo Puanna La Sengngeng, who undertook the task by order of La Mappajung Puanna Salowong, the ruler of Wajoq from 1764 until 1767 (Zainal Abidin 1985: 32-33).

14 In this context it is noteworthy that Matthes makes no mention of such a work.

15 Abdurrazak Dg. Patunru (1983: 8-12) mentions five different Wajoq origin traditions.

16 She was also known as Retna Kencana and her title was Arung Pancana Toa.

17 A copy of this work was later published in the Bugis script by Niemann (1883), which has been translated into Indonesian on two occasions: Musa et al. (1990) and Gising (2002).

18 By comparison, the lontaraq Simprusia from Luwuq opens with the words "May [my] mouth be torn open, may [my] tongue be torn out, may my head be split open [should] I cause offense]; may I not swell for setting out in order the descendants of the great ones" (Caldwell 1988: 42).

19 Recent work on the South Sulawesi Tributary and Domain Lists suggests that many boundaries had been set out shortly after the Makassar Wars in the late 17th century and changed little in later years (Druce 2014). I am under the impression that Haji Paewa had created much of his work in the 1970s, which also included a number of genealogies, the early sections of which are highly unreliable (see Druce 2009: 169-173).

21 A comparison between the earlier versions of these traditions and those collected by Haji Paewa appears in Druce (2009: 81-90).

22 I met Haji Paewa in 2001 but he was too ill to hold any meaningful conversation.

23 Two related versions of this work are known (Caldwell 1988: 140-148; Druce 1999). Here I focus here on the longer version (Druce 1999).

24 Examples of such glosses are "At the time of the seven arung (lords) who first opened Sidénréng" and "These are also the words that were spoken by the people who first opened the land of Sidénréng."

Her name is also the last to appear on a list of Sawitto rulers presented by the writer. Later, a handwritten name was added to this list, presumably by whoever inherited the manuscript.

26 A few of Cense's surviving papers are held by the Koninklijk Instituut voor Taal-, Land- en Volkenkunde in the University of Leiden library.

27 An annotated reproduction of the original unedited text is presented in the appendix.

28 Pajung (umbrella) was the title of the paramount ruler of Luwuq.

29 A female nocturnal long-tailed cuckoo (Eudynamys orientalis).

30 The reply appears to be from the elder sibling, who later becomes ruler of Sawitto.

31 An unconvincing explanation of the etymology of the name Sidénréng derived from kalelleng, "dark."

32 The claim here is that Rappang is derived from the word reppang/rappang: debris, such as branches and twigs, washed away that have piled up. A possible alternative is that the word may be derived from reppaq, which means broken (Matthes 1874: 491), and that the river was piled with broken objects.

33 A well-known etymology of the name Sawitto.

34 An addition that recalls a memory of when the course of the river Saddang was different than today. 
35 The latter part of this sentence is vague and the translation represents my interpretation.

36 A being from the Upperworld sent to rule over common people. Here tomanurung refers to the parents of the eight children and serves to make known they are of divine origin. The mother's association with water foam suggests a totompoq, one who ascends from the Underworld. Both are later referred to as (to)manurung.

37 This presumably is the sister, who would have gone to the market to sell produce.

38 It is not clear here whether the tradition is referring to the servant of the ruler or someone else.

39 With the exception of Cempa, all the lands named as defeated by the siblings are listed as directly ruled in Sawitto's tributary and domain list and formed the core of the kingdom.

40 The six lords.

41 The title is unknown from other oral and written sources and is discussed in a later section.

42 From padang, the common area found in most villages.

43 The concept of white-blood is found among all South Sulawesi language group speakers.

44 This section appears refers to the brother who became ruler of Sawitto.

45 Saoraja (palace); toriaqdatuangng (the one who was sent); aqdatuang (title for Sawitto rulers used in most oral and written sources).

46 Petta, lord.

47 An etymology of the name Alitta, which the tradition claims is derived from anritta ("our younger sibling").

48 The literal meaning of wessé asé mappammasaq is "we germinate our own rice ourselves." The translation given by the $h \mathrm{~S}$ 's creator supplies the correct meaning of the metaphor.

49 Most written and oral sources place the male pronounal gender indicator "La" before Celaqmata, as it appears in a later section, and the female pronounal gender indictor "Wé" before the name of his sister. For females "I" or "E" is often substituted for "Wé" in many Bugis oral and written sources, a matter of style and local variation. The name Jépo is usually rendered as Gémpo in most written genealogies but occurrences of Gimpo and Jémpo are also found.

50 Massépé is an iron-working village in Sidénréng. "Basoq" means crown prince.

51 "Matinroé ri Maroli?": The last two letters of the original text are marked and cannot be read clearly. In the list of rulers presented later the name Torijallo is followed by the posthumous name matinroé ri Tamanroli.

52 Lontaraq are indigenous writings in the Bugis script.

53 An explanation of who she was betrothed to is missing from the text. The story becomes clear below.

54 The word cakkaridi refers to a title associated with Wajoq. Matthes' (1874: 419) spelling is cakoridi while in most written genealogies from the Ajattappareng region the spelling is cakkuridi.

55 This additional information is probably wrong. Makuring and Patombong are not a single place but two separate villages that formed the domain of Langa, a tributary 
of Sawitto. Large quantities of ceramics have been found in Makuring suggesting it may have been where Langa's rulers lived (see Druce 2009: 126-127, 256-257).

The title datu (ruler) was used by the rulers of Suppaq and several other kingdoms. La Patombongi does not appear in any in any oral or written genealogies from the Ajattappareng region as a datu of Suppaq or otherwise.

57 Again the information is wrong. Ajattappareng genealogies and other sources are consistent in stating that the first ruler to convert to Islam was Wé Passullé. I address this issue below.

58 Datuk (sometimes Datok) ri Bandang was one of three Islamic teachers credited with bringing Islam to South Sulawesi.

59 The rulers of Gowa and Talloq named here are unknown and bear no resemblance to those who first converted to Islam. For Gowa this was Sultan Ala'uddin, posthumously known as Tumamenang ri Gaukanna, for Talloq, it was Karaeng Matoaya, also known as Sultan Abdullah and posthumously as Tumamenang ri Agamana. The short account that follows is, however, broadly correct.

60 This is an interesting addition. The rulers of Suppaq, and perhaps Sawitto, converted to Catholicism in the mid-16th century, as recorded in Portuguese sources (Mills 1930: 55-56; Jacobs 1966, Baker 2005; Druce 2009: 238-240). It is impossible to know whether the addition was made by the $h S$ 's creator or the informants and whether it reflects a memory of this conversion, or was simply information conveyed by a Dutch official, such as Cense. I have been informed orally by people in the Ajattappareng region that Suppaq's rulers once converted to Christianity; my assumption was that this claim originated in modern printed sources (for example, Pelras' 1983 publication in Indonesian) that were fed into the oral register.

61 Musuq sellengngé: "the wars of Islamisation."

62 According to Matthes (1874: 234) besséq is a title of princesses.

63 "He who sleeps in the mosque." This posthumous name is usually associated with an 18th century Sawitto ruler called La Kunneng, who appears below. His grave can still be found outside the remains of a mosque in Sawitto's former palace centre (Druce 2009: 125).

64 "Andi" is a Bugis title. Today it is universally applied to all Bugis who are descended from the former ruling elite, regardless of rank.

65 In written genealogies the name of La Cibu's sister is Wé Cindéq. The name Tanunnuq does not appear in these genealogies.

66 The anaq mattola were the children of highest rank and those who could succeed as rulers.

67 This is the Wé Pasullé above.

68 Anaq sengeng: of pure royal blood.

69 The literal meaning of palorong wélareng patjolli raukkaju is "to make the vegetation creep and trees sprout leaves."

70 Most sources use the term Eppa baté-baté (the four flags) instead of Paqbaté-baté (the flag holders). The Eppa baté-baté were the four most important tributaries of Sawitto. According to traditions collected by Van Braam Morris (1892: 214), the Eppa baté-baté tributaries were Rangaméa, Tiroang, Langa and Loloang. The inclusion of Jampué and Pénrang at the expense of Rangaméa and Tiroang appears a recent change, perhaps related to Rangaméa and Loloang losing some strategic 
importance when the river Saddang changed its course in the late 19th century. Both lands were abandoned some time before Indonesian independence (Druce 2009: 103, 126). Laleng Bata refers to Sawitto's palace centre.

71 Some written genealogies have Wé Béda, most have Wé Baéda.

72 There are a number of problems and inaccuracies with the genealogical list presented below. I discuss some of the problems following the translation.

73 Most written genealogies indicate this ruler was female, not male, and her full name was Wé Timeng Petta Battoaé.

74 Not known from written genealogies.

75 This is probably the Sawitto ruler To Dani. He followed La Toraja, who is named below.

76 Not identified in written genealogies. La Tenritatta followed To Dani as Sawitto ruler.

77 Not identified from written genealogies. La Doko followed La Teritatta.

78 Wé Cidéq (or Cindéq) was the daughter of La Kuneng, whose name appears below. She replaced her sister Wé Timeng as ruler of Sawitto, who does not appear on the list. Her younger brother La Cibu, who appears further down in the list, succeeded her as ruler of Sawitto.

79 La Wawo was not a ruler of Sawitto but of Sidénréng during the first half of the 19th century.

80 Not recognised from written genealogies.

81 The father of Wé Timeng, Wé Cidéq and La Cibu.

82 Succeeded his sister, Wé Cidéq, as ruler of Sawitto.

83 Probably La Pallagau who replaced his wife, Wé Passullé, after her death.

84 The 26th name is a later addition by one or more people. Sensi Radda is written by hand in the Latin script, followed by Arung Rappang in the Bugis script. Baéda's successor as ruler of Sawitto was Arung of Rappang but her name was Wé Tenri, not Sensi Radda.

85 The ulu anang were leaders of the common people.

86 A civil judge dealing with Muslim affairs.

87 This information indicates that the creator of the $h \mathrm{~S}$ is unlikely to have been from Sawitto's elite.

88 To ri: "people of."

89 The sentence should be read in the context of Sawitto, and the other Bugis, kingdoms, coming under direct Dutch rule in 1905. This inevitably had an important impact on the succession processes.

90 I use the term "precedence" in the sense meant by Fox (1996: 131-132). For a discussion of origin and precedence in relation to South Sulawesi see Druce (2009: 159-199).

91 A visible connection between Toraja and the Sawitto region still seen today is the shape of the baruga (a structure built on to the front of a house when a marriage takes place) that is used by those of royal blood. The baruga of Sawitto nobles is similar in shape to the saddle roofs of Toraja tongkonan (origin house) while people of common descent can only erect a standard baruga of the type commonly found in other Bugis-speaking areas (Druce 2009: 188-189).

92 One example is the attoriolonna Soppéng (Caldwell 1988: 99). 
93 A similar concept is found in the Polynesian islands of Hawaii and Tonga, as Claessen (2000: 709) writes: "The chiefs guaranteed (or created, or promised) fertility and well-being [...] and the people worked for the chiefs and handed over their products and daughters to them. The system worked satisfactorily-as long as the chiefs fulfilled their part of the 'deal' by procuring fertility and well-being. Where this was not (or no longer) the case, a chief could be rejected."

According to the late Drs Muhammad Salim, aqdaoang means to provide shelter, possibly referring to the dao tree (Dracontomelon mangiferum). The title changed to aqdatuang (one who is made datu) following the acceptance of Islam.

95 For examples of oral genealogies and ruler lists collected in modern times see Druce (1997: 33) and Druce (2009: 51-52, 186, 191-193).

96 Caldwell (1988) has argued that the first effective use of writing in South Sulawesi was to record genealogical information about the ruling elite from about 1400. This was probably the main motive for the development of writing (Macknight 1993: 11). Some written genealogies for Sawitto state that Wé Pasullé and To Pataka had three children: La Tenrisessuq, Wé Tenripakkiya and Wé Tenriséno. Her successor as ruler of Sawitto appears to have been La Tenrigau (or Tenripau). She should not be confused with the Wé Pasullé who appears in the latter part of the tradition. This is a different person.

99 The final tradition presented in the $h S$ that the creator read in a manuscript from Langa also refers to Wé Pasullé through her posthumous name and sets out that Sawitto rulers should be genealogically linked to this ruler who connects the preIslamic and Islamic worlds. The writer simply presents this tradition without comment, unaware of her importance.

100 "aratoes" reads "ratoes."

101 "alnggahlah" reads "singgalah."

102 a-a Speech and question marks missing.

103 This Bugis word is usually spelt "kalellang" (dark).

104 "si" reads "di."

105 b-b Speech and question marks missing.

106 "dimanai" reads "dinamai."

107 "Djawa" reads "Djawab."

108 "sisitoe" reads "disitoe."

109 c-c $^{\mathrm{c}}$ Speech and question marks missing.

110 "singgallah" reads "tinggallah."

111 "Pallataoeng" reads "Paleteang."

112 Not a Bugis word, origin and meaning unknown.

113 Probably "chajalnja" (modern spellings: khayalnya), "his vision/hallucination."

114 A Bugis word.

115 Bugis word.

116 d-d Bugis words.

117 e-e "itoe soesoe" reads "itoe iboe soesoe."

118 "isterri" reads "isteri."

119 "boelah" reads "belah."

120 "isreri" reads "isteri."

121 This presumably is the female sibling. 
122 "anoegarahkan": probably from the Malay spelling of the word. Modern Indonesian spelling is "anugerahkan."

123 "berang" reads "barang."

124 "moesoe" should be "moesoeh."

125 "nail" reads "naik."

126 "leistana" reads "keistana."

127 "ohidmat" should probably read "chidmat."

128 "menaloekkan" reads "menakloekkan."

129 "Palleteang" reads "Paleteang."

130 A Bugis word.

131 The writer's translation of the Bugis omits the last part of the phrase and and contains one spelling error. It should read: "kehendakmoe berlakoe perkataanmoe jang benar di tanah Sawitto." In the translation, "she" replaces the vague term "orang itoe."

133 "Palleteang" reads "Paleteang" and again in the repetition of this toponym that follows.

The alternative spelling of the toponym Peso' given by the writer is the correct one. This repetition of Boeloe probably represents a mistake by the teller of the story.

"Palletenng" read "Paleteang" and again below.

f-f Bugis words.

"disoedoel" 'reads "disoesoel."

Speach marks missing.

"boeah-boeahhanpoen" reads "boeah-boeahanpoen."

g-g Bugis words: "white blood."

"dipintanjalah" reads "dimintanjalah."

"doe" reads "doea."

The words "maka bakau?" make no sense in this context. The use of a question mark "bakau" (mangrove) suggests that the writer was unsure of the word, perhaps unable to read the handwriting correctly when the work was typed. It should probably read "berkaul" (to take a vow), an interpretation I follow in the translation. "niatjaja" should probably read "niat djaja."

"dank e" reads "dan ke."

A Bugis word.

Bracket is missing.

"berroemah" reads "beroemah."

Read "itoe."

The rest of the word is unreadable.

The speech marks used in this paragraph follow no logical sequence and are omitted from the translation.

This should read "Lampe'weloea," as it appears in the next line of the sentence.

"ragja" reads "radja."

"Lamakkassoe" reads "Lamakkasaoe" as above.

The term "igama" is correct. It was used until the 1930s in reference to the three monotheistic religions (Feillard 2011: 51).

Correctly, "Datuk ri Bandang."

"mato" reads "mati." 
159 "pangga" read "panggah."

160 A Bugis word.

161 "dati" reads "dari."

162 A Bugis word.

163 The word "mentjahatikan" has no meaning and is presumably a typing error, which makes it difficult to represent the writer's rudimentary translation of the proceeding Bugis phrase. In the translation I have inserted my own non-literal meaning based on my correction of the Bugis phrase, which is frequently foud in both oral and written traditions.

164 "denngan" reads "dengan."

165 "gentinja" reads "gantinja."

166 "Saeda" reads "Baeda."

167 "katjiboe" reads "LaTjiboe."

168 "Laleng-Baata" reads "Laleng-Bata."

169 "sebba" reads "sebab."

170 Bugis words.

171 Bugis words.

172 "Aeatoeang" reads "A'deatoeang."

173 A Bugis word.

174 "kajoem" reads "kajoe."

\section{REFERENCES}

Baker, B. 2005. South Sulawesi in 1544: A Portuguese letter. Review of Indonesian and Malaysian Affairs 39 (1): 61-85.

Caldwell, I. A. 1988. South Sulawesi AD 1300-1600: Ten Bugis texts. PhD diss., Australian National University, Canberra.

Caldwell, I. and Wellen, K. 2016. Family matters: Bugis genealogies and their contribution to Austronesian studies. In Orality, writing and history: The literature of the Bugis and Makasar of South Sulawesi, ed. Druce, S. C. International Journal of Asia Pacific Studies 12 (Supp. 1): 119-141, http://dx.doi.org/10.21315/ijaps2016.12.s1.6.

Claessen, H. 2000. Ideology, leadership and fertility: Evaluating a model of Polynesian chiefship. Bijdragen tot de Taal-, Land- en Volkenkunde 156 (4): 707-735.

Cummings, W. 2000. Reading the histories of a Maros chronicle. Bijdragen tot de taal-, land- en volkenkunde 156 (1): 1-31. 2007. A chain of kings: The Makassarese chronicles of Gowa and Talloq. Leiden: KITLV Press.

Druce, S. C. 1997. Report on the Vassal List of Soppéng. Report to the South-East Asia Committee of the British Academy. Available at http://www.oxis.org/resources-3/unpublished/druce-1998.pdf. . 1999. The Mula Tattimpaqna Sidénréng: A historical text from Sidénréng'. MA diss., University of Hull, United Kingdom. 
. 2009. The lands west of the lakes: A history of the Ajattappareng kingdoms of South Sulawesi, 1200 to 1600 CE. Leiden: KITLV Press. . 2014. Dating the tributary and domain lists of the South Sulawesi Kingdoms. In Cetusan minda sarjana: Sastera dan budaya, ed. Ampuan Haji Tengah, A. H. B., 145-156. Brunei: Dewan Bahasa dan Pustaka.

Feillard, A. 2011. The constrained place of local tradition: The discourse of Indonesian traditionalist ulama in the 1930s. In The politics of religion in Indonesia: Syncretism, orthodoxy, and religious contention in Java and Bali, eds. Picard, M. and Madinier, R., 48-70. London: Routledge.

Fox, J. J. 1996. The transformation of progenitor lines of origin: Patterns of precedence in eastern Indonesia. In Origins, ancestry and alliance: explorations in Austronesian ethnography, eds. Fox, J. J. and Sather, C., 130153. Canberra: Department of Anthropology, Research School, Australian National University.

Gising, B. 2002. Sejarah kerajaan Tanete (terjemahan dari G. K. Nieman, 1883, Geschiedenis van Tanete). Makassar: Samajaya.

Goody, J. 1987. The interface between the written and the oral. Cambridge: Cambridge University Press.

Goody, J. and Watt, I. 1968. The consequences of literacy. In Literacy in traditional societies, ed. Goody, J., 27-68. Cambridge: Cambridge University Press.

Jacobs, H. 1966. The first locally demonstratable Christianity in the Celebes, 1544. Studia 17: 251-305.

Koolhof, S. 1999. The 'La Galigo': A Bugis encyclopedia and its growth. Bijdragen tot de Taal-, Land- en Volkenkunde 155 (3): 362-387.

Macknight, C. C. 1984. The concept of a 'work' in Bugis manuscripts. Review of Indonesian and Malaysian Affairs 18: 103-14. . 1993. The early history of South Sulawesi: Some recent advances (working paper 81). Clayton: Centre of Southeast Asian Studies, Monash University. . 2000. South Sulawesi chronicles and their possible models. In Vasco da Gama and the linking of Europe and Asia, ed. Disney, A. and Booth, E., 322332. New Delhi: Oxford University Press.

Macknight, C. C. and Mukhlis. n. d. The chronicle of Boné. Unpublished manuscript.

Matthes, B. F. 1872. Aanteekeningen op de Boeginesche chrestomathie. Amsterdam: Spin

. 1874. Boegineesch-Hollandsch woordenboek met Hollandsch-Boegineesche woordenlijst, en verklaring van een tot opheldering bijgevoegden ethnographischen atlas. Amsterdam: M. Nijhoff.

Mills, J. V. 1930. Eredia's description of Malacca, meridional India and Cathy. Translated from the Portuguese with notes. Journal of the Malayan Branch of the Royal Asiatic Society 8 (1): 1-288.

Mukhlis et al. 1985. Sejarah daerah TK.II Sidénréng-Rappang. Ujung Pandang: Universitas Hasanuddin. 
Musa, H. A. G. et al. 1990. Iyanae paoda adaengngi attoriolongnge ri Tanete (sejarah kebudayaan Tanete). Jakarta: Departemen Pendidikan dan Kebudayaan, Direktorat Jenderal Kebudayaan, Direktorat Sejarah dan Nilai Tradisional, Proyek Penelitian dan Pengkajian Kebudayaan Nusantara.

Niemann, G. K. 1883. Geschiedenis van Tanette. Boeginesche tekst met aanteekeningen. 's-Gravenhage: M. Nijhoff.

Noorduyn, J. 1955. Een achttiende-eeuwse kroniek van Wadjo': Buginese historiography. 's-Gravenhage: H. L. Smits.

Ong, W. J. 1982. Orality and literacy: The technologizing of the word. London: Methuen.

Paeni, M. et al. 2003. Katalog induk naskah nusantara Sulawesi Selatan. Jakarta: Arsip Nasional R. I. (ANRI) Jakarta.

Patunru, A. D. 1983. Sejarah Wajo. Ujung Pandang: Yayasan Kebudayaan Sulawesi Selatan.

Pelras, Ch. 1983. Sulawesi Selatan sebelum datangnya Islam berdasarkan kesaksian bangsa asing. In Citra Masyarakat Indonesia, ed. Harmonic, G., 56-83. Jakarta: Sinar Harapan. . 2016. Orality and writing among the Bugis, trans. Macknight, C. C. In Orality, writing and history: The literature of the Bugis and Makasar of South Sulawesi, ed. Druce, S. C. International Journal of Asia Pacific Studies 12 (Supp. 1): 13-51, http://dx.doi.org/10.21315/ijaps2016.12.s1.3.

Rahim, A. and Borahima, R. 1975. Sejarah kerajaan Tallo': Suatu transkripsi lontara'. Ujung Pandang: Lembaga Sejarah dan Antropologi.

Reid, A. 1998. Merdeka: The concept of freedom in Indonesia. In Asian freedoms: The idea of freedom in East and Southeast Asia, eds. Kelly, D. and Reid, A., 141-160. Cambridge: Cambridge University Press.

Sneddon, J. N. 2003. The Indonesian language: Its history and role in modern society. Sydney: University of New South Wales Press.

van Braam Morris, D. F. 1892. Nota van toelichting op het contrakt gesloten met het landschap Maiwa, Doerie, Kassa, Batoelappa, Alietta, Soeppa, Sawieto. Tijdschrift voor Indische Taal-, Land- en Volkenkunde 36 (2): 152-230.

van den Brink, H. 1943. Dr. Benjamin Frederik Matthes: Zijn leven en arbeid in dienst van het Nederlandsch Bijbelgenootschap. Amsterdam: Nederlandsch Bijbelgenootschap.

Vansina, J. 1985. Oral tradition as history. London: Currey.

Wellen, K. A. 2014. The open door: Early modern Wajorese statecraft and diaspora. DeKalb, Illinois: Northern Illinois University Press.

Wolhoff, G. J. and Abdurrahim. 1959. Sejarah Goa. Ujung Pandang: Jajasan Kebudajaan Sulawesi Selatan and Tenggara.

Zainal Abidin, A. 1985. Wajo' pada abad XV-XVI: Suatu penggalian sejarah terpendam Sulawesi Selatan dari Lontara. Bandung: Alumni. 